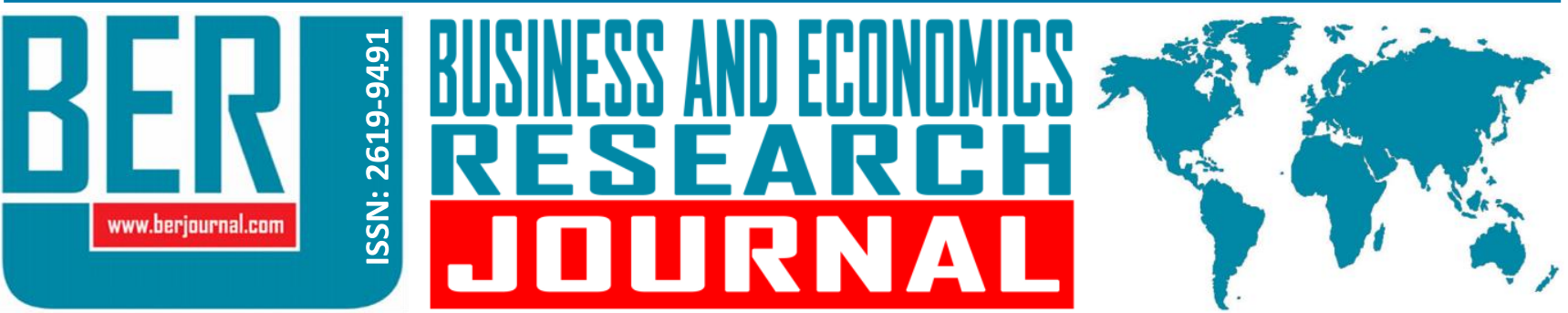 \\ Business and Economics Research Journal Vol. 12, No.1, $2021 \quad$ pp. 197-217 doi: 10.20409/berj.2021.318
}

\section{Müşteriyi Anlamada Güncel Bir Yaklaşım: Müşteri İlginliği Üzerine Bir Literatür Taraması ${ }^{1}$}

\section{Nilsah Cavdar Aksoy ${ }^{\text {a }}$, Ebru Tumer Kabadayı ${ }^{\text {b }}$, Alev Kocak Alan ${ }^{\mathrm{c}}$, Coskun Ermehan ${ }^{\mathrm{d}}$}

Öz: Günümüzde müşteriler, firma veya marka ile iletişimlerinde yalnızca satın alma gibi sonuca yönelik davranışlar sergilememekte, 'müşteri ilişkileri' sürecinde aktif bir katılımcı olarak yer almaktadır. Bu bakımdan, güncel bir yaklaşım olarak dikkat çeken müşteri ilginliği, pazarlamanın yıllar içerisinde değişen odağını temsil etmektedir. Hem akademinin hem işletme dünyasının yoğun ilgisiyle karşı karşıya olan müşteri ilginliği, bu çalışmada bir literatür incelemesi vasıtasıyla araştırılmıştır. 397 makale; müşteri ilginliğine yaklaşımları, inceledikleri konular, teorik dayanakları, ele aldıkları müşteri ilginliği ardılları ve öncülleri bakımından içerik analizine tabi tutulmuş ve tasnif edilmiştir. Makalelere ait yıl ve yayınlandıkları dergi bilgileri baz alınarak bir bibliyometrik analiz de gerçekleştirilmiştir. Incelenen makalelerde çoğunlukla, müşteri ilginliğinin nasıl sağlanabileceğine dair uygulama yöntemlerine odaklanıldığı, buna yönelik olarak çevrimiçi marka toplulukları ve sosyal medya uygulama alanları gibi konuların incelendiği, hizmet baskın mantığa dayalı kullanıldığı görülmüştür. En sık rastlanan müşteri ilginliği öncülleri deneyim, fayda ve güdüler, güven iken; yoğunlukla incelenen müşteri ilginliği ardılları müşteri sadakati, sosyal varlık gösterme, kendini adama şeklindedir. Çalışma bulguları neticesinde, işletme dünyası için bir mevcut durum analizi ve akademi için araştırma önerileri sunulmuştur.

\section{A Current Approach to Understand Customers: A Literature Review on Customer Engagement}

\begin{abstract}
In today's business world, customers do not only behave in a consequence-oriented way in their communication with the company or the brand such as purchasing. They are active participants in the "customer relationships" process. As a reflection of this, customer engagement represents the changing focus of marketing. Customer engagement, which draws attention as a timely approach both in the business world and academia, was investigated in this study through a literature review. 397 articles were classified via content analysis in terms of their approach to customer engagement, the topics they examined, their theoretical backgrounds, the antecedents and consequences they handled and explained. A bibliometric analysis was also conducted based on the publication year of the articles and the journal they were published in. Our literature review shows that the focus is on the application areas of customer engagement mostly, common topics in the studies are online brand communities and social media application areas, and the service dominant logic is often used as theoretical background. While the most common antecedents of customer engagement are experience, benefits and motives, and trust, its most common consequences are customer loyalty, social presence, and commitment. Based on the study findings, an analysis for the current situation of customer engagement for the business world and research suggestions for the academia are presented.
\end{abstract}

Anahtar Sözcükler: Ilginlik, Müşteri İlginliği, Tüketici ilginliği

JEL: M30, M31

$\begin{array}{ll}\text { Geliş } & : 25 \text { Eylül } 2020 \\ \text { Düzeltme } & : 25 \text { Kasım } 2020 \\ \text { Kabul } & : 25 \text { Ocak } 2021 \\ & \\ \text { Tür } & : \text { Derleme }\end{array}$

Keywords: Engagement, Customer Engagement, Consumer Engagement

JEL: M30, M31
Received : 25 Ocak 2021

Revised : 25 November 2020

Accepted : 25 January 2021

Type : Review

a Res. Asst., Gebze Technical University, Faculty of Business Administration, Department of Business Administration, Kocaeli, Turkiye, n.cavdar@gtu.edu.tr (ORCID ID: 0000-0003-0734-3930)

b Prof., PhD., Gebze Technical University, Faculty of Business Administration, Department of Business Administration, Kocaeli, Turkiye, tumer@gtu.edu.tr (ORCID ID: 0000-0002-0673-6866)

Assoc. Prof., PhD., Albeka Consulting, Istanbul, Turkiye, alev.alan@albekaconsulting.com (ORCID ID: 0000-0002-1060-1593)

d Gebze Technical University, Faculty of Business Administration, Department of Business Administration, Kocaeli, Turkiye, coskunermehan@gmail.com (ORCID ID: 0000-0002-5768-7080) 


\section{Giriş}

Günümüz müşterileri, dijital dünyanın tüketim alanında ortaya çıkardığı gelişmeler sayesinde, ihtiyaçları hakkında daha kolay bir biçimde bilgiye ulaşır ve bilgi paylaşır hale gelmiştir (Koufaris, Kambil ve LaBarbera, 2010). Elde ettikleri bu güçle müşteriler, satın alma kararı verirken seçenekleri rahatlıkla karşılaştırabilmekte, kendilerine uygun seçeneği bulabilmekte ve satın alma sonrası değerlendirmelerini de dijital ortamlarda çok sayıda kişiyle paylaşabilmektedirler (Dellarocas ve Narayan, 2006). Bu durum, müşterilerle kurulacak olan ilişkilerin farklı bir boyut kazanmasına ve bu yeni nesil müşterilerle ilişkilerin yönetimi konusunda da yeni bakış açılarının oluşmasına neden olmuştur (Malthouse, Haenlein, Skiera, Wege ve Zhang, 2013). Geleneksel müşteri ilişkileri yönetiminde müşteri, firma ile olan ilişkisinde yalnızca sunulanlara satın alma gibi bir biçimde yanıt vererek pasif bir rol oynuyorken, sosyal medyanın yaygınlaşmasıyla sosyal bir hal alan bu ilişkide, sunduğu tüm geri dönüşlerle firmaya ilginlik gösteren aktif bir katılımcıya dönüşmüştür.

Müşteri ilginliği, en geniş tanımıyla, bireyin müşteriler veya firma tarafından sunulan teklif / faaliyetlere katılma / bunlarla bağlantı kurma yoğunluğudur (Vivek, Beatty ve Morgan, 2012). Çeşitli davranışlar içeren bu kavram (ağızdan ağıza iletişim, öneriler sunma, diğer müşterilere yardım etme, blog oluşturma, incelemeler yazma, yasal işlemlerde bulunma), ortaya çıkardığı farklı bağlamlardaki etkilerle (müşteriler, firma veya toplum odaklı) de dikkat çekmektedir (Van Doorn vd., 2010). Özellikle işletme-müşteri arasındaki çift yönlü iletişimin yüksek olmasına imkân tanıyan dijital kanallarda, müşteri için değer yaratma noktasında karşımıza çıkan müşteri ilginliği, günümüzde işletmelerin pazarlama politikalarını şekillendirmektedir (Kumar vd., 2010; Harmeling, Moffett, Arnold ve Carlson, 2017). Pansari ve Kumar (2017) müşteri ilginliğinin günümüz pazarlama dünyasındaki gerekliliğini, müşteri yönetiminin yıllar içerisindeki gelişimi çerçevesinde açıklamışlardır. Pansari ve Kumar (2017)'a göre, pazarlamanın odağı yıllar içerisinde "işlem"den "ilişki"ye ve neticesinde "ilginlik"e evrilmiştir. Çünkü yöneticiler ve akademisyenler, yalnızca müşteri memnuniyeti oluşturmanın ve müşterileri sadık ve kar sağlayan müşteriler haline getirmenin yeterli olmadığını, bunun ötesine geçmek gerektiğini anlamışlardır.

Illginlik kavramı; sosyoloji, psikoloji, örgütsel davranış, siyasi bilimler gibi birçok akademik disiplin için yeni bir kavram değildir ve ilginliğin, 2000'li yılların başından itibaren, bu çeşitli disiplinlerde farklı bağlamlarda tartışıldığı bilinmektedir (Brodie, Hollebeek, Jurić ve Ilić, 2011). 2005 yılından beri pazarlama alanında giderek artan bir biçimde kullanılmaya başlanan ilginlik kavramının (Brodie llic, Juric ve Hollebeek, 2013), diğer akademik disiplinlere nazaran pazarlama alanında yaygınlaşmasının nispeten daha yeni olduğu ifade edilmektedir (Paruthi ve Kaur, 2017). Pazarlama çevrelerinde müşteri ilginliği kavramının ilk kullanımlarından biri olarak, uluslararası bir danışmanlık şirketi olan Gallup, "Müşteri ilginliğinin 11 Göstergesi" adlı bir çalışma yayınlamıştır (Appelbaum, 2001). Akademik çevreler ise bu kavramı incelemeye, Gallup'un yazısından yaklaşık 4 yıl sonra, 2005 yılından itibaren başlamıştır (Sawhney, Verona ve Prandelli, 2005). Marketing Science Institute'ün 2010-2012 ve 2014-2016 yıllarındaki araştırma öncelikli alanlar listelerinde temel alan ilan edilen müşteri ilginliği, Kumar ve Pansari (2016) tarafından da akademik ilgiye ihtiyaç duyulan yükselen bir araştırma alanı olarak tanımlanmıştır. Günümüzde hala akademi için nispeten yeni olarak adlandırılan bu alan, son yıllarda işletmeler tarafından açığa çıkması arzulanan pek çok tüketici davranışını meydana getirmesi bakımından, akademinin ve yöneticilerin ilgisini çekmektedir (Islam ve Rahman, 2016). Türkçe literatürde ise, müşteri ilginliği kavramına yönelik yoğun bir ilgi gözlemlenmemekte ve hatta, kavramın Türkçeleştirilmesi noktasında dahi henüz başlangıç aşamasında olunduğu ve bir fikir birliğine varılmamış olduğu görülmektedir. Bu bakımdan, müşteri ilglinliğinin bir davranış olarak pazarlama literatürü için öneminin açıklanmasına duyulan ihtiyaç nedeniyle ve Türkçe literatürdeki araştırma boşluğundan hareketle, bu çalışmada müşteri ilginliği üzerine bir literatür taraması gerçekleştirilmiştir. Çalışmanın amacı; (i) tüketici davranışları literatüründeki bu güncel yaklaşımı derinlemesine analiz etmek, (ii) müşteri ilginliği kavramının Türkçeleştirilmesi ve Türkçe literatürün bu bağlamda geliştirilmesine katkı sağlamak ve (iii) müşteri ilginliği çalışmalarını inceleyerek kavramın dünü ve bugününü anlamak, buradan hareketle iş dünyası için bir mevcut durum analizi sunmak ve gelecek çalışmalar için ise bir araştırma ajandası oluşturmaktır. Çalışmada, Web of Science (WOS) veri tabanı üzerinden bir literatür incelemesi yapılmış ve 
ulaşılan çalışmalar çeşitli bakımlardan içerik analizine tabi tutularak müşteri ilginliği üzerine derinlemesine bilgi sunulmuştur.

\section{Literatür Çalışması}

Literatürde müşteri ilginliğini kavramsallaştırmaya yönelik çeşitli çalışmalar yürütülmesine rağmen, müşteri ilginliğinin tanımı ve kavramı oluşturan boyutlarla ilgili bir fikir birliği sağlanamamıştır (Graffigna ve Gambetti, 2015; Paruthi ve Kaur, 2017). Bu çalışmalar incelendiğinde, bazı temel alınabilecek yaklaşımlar dikkat çekmekte ve diğer çalışmaların bu temel yaklaşımları takip ederek kendi bakış açılarına uyarladıkları görülmektedir. Bu bağlamda dikkat çeken çalışmalardan biri, literatürde oldukça yüksek bir atıf sayısına sahip olan Van Doorn vd. (2010)'nin çalışmasıdır. Bu yazarlar, müşteri ilginliğini davranışsal bir bakış açısıyla ele almakta ve bu kavramı, yalnızca ticari işlemlerle sınırlı olmayan, bunun ötesine geçen, marka veya firma odaklı, satın almanın ötesinde ve motivasyonel faktörlerle açığa çıkan müşteri dışavurumları olarak tanımlamaktadırlar. Etki düzeyi yüksek diğer bir çalışmada, Brodie vd. (2011) kavramın psikolojik yönünü ön plana çıkararak müşteri ilginliğini; bir hizmet ilişkisinde, ilgili taraf ile (örn. bir marka) etkileşimli ve birlikte değer yaratılan bir müşteri deneyimi sayesinde gerçekleşen psikolojik bir durum olarak tanımlamaktadırlar. Vivek vd. (2014) ise, etki düzeyi yüksek olan çalışmalarında, kavramın etkileşim ve sosyal bağlantı yönüne dikkat çekmektedirler. Yazarlar müşteri ilginliğini, müşterinin veya potansiyel müşterinin markanın/firmanın teklifleri/faaliyetleriyle olan etkileşim ve bağlantı seviyesi olarak tanımlamakta ve bu kavramın satın almanın ötesine geçtiğini, genellikle bireyleri marka, teklif/faaliyetler etrafında oluşturulan sosyal ağa dahil ettiğini vurgulamaktadırlar. Tablo $1^{\prime}$ de, bahsedilen etki düzeyi yüksek, literatüre yön veren müşteri ilginliği tanımlarını ve neticesinde sunulan, ilginlik kavramını tanımlamaya yönelik yeni bakış açıları veya bağlam uyarlamaları aktaran bazı çalışmalar listelenmiştir.

Müşteri ilginliği üzerine yapılan çalışmalar, kavramı oluşturan boyutlar konusunda da farklı görüşlerin varlığını göstermektedir. Bu bağlamdaki yaygın görüş; müşteri ilginliğinin bilişsel, davranışsal ve duygusal boyutlardan oluştuğu şeklindedir (Busalim vd., 2019). Ancak literatürde, ilginliğin tek boyutlu (örn. van Doorn vd., 2010), iki boyutlu (Dijkmans, Kerkhof ve Beukeboom, 2015) veya dört boyutlu (Vivek, Beatty, Dalela ve Morgan, 2014) olarak ele alındığı çalışmalar da bulunmaktadır. Hollebeek (2011) bu durumu, ilginliğin bağlam özelinde boyut bakımından farklılaşabileceğini vurgulayarak açıklamaktadır. Örneğin Hollebeek'e (2011) göre, çevrimiçi ortamda, çevrimdışı ortamda, markaya yönelik, örgüte yönelik ilginlik davranışlarının içerdiği boyutların farkıı olması olağandır. Tablo 1, aynı zamanda, müşteri ilginliği kavramını tek boyutlu veya çok boyutlu olarak ele alan çalışmaları da göstermektedir.

Tablo 1. Müşteri İlginliğinin Tanımı ve Boyutları

\begin{tabular}{|c|c|c|c|}
\hline Yaklaşım & Boyut & Tanım & Kaynak \\
\hline \multirow{5}{*}{$\begin{array}{l}\frac{.}{\overline{0}} \\
\frac{\overline{0}}{\overline{0}} \\
\frac{\bar{n}}{\square}\end{array}$} & \multirow{5}{*}{ 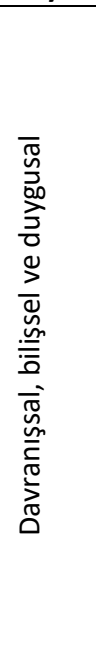 } & $\begin{array}{l}\text { Bir hizmet ilişkisinde, ilgili taraf ile (örn. bir marka) etkileşimli } \\
\text { ve birlikte değer yaratılan bir müşteri deneyimi sayesinde } \\
\text { gerçekleşen psikolojik bir durum (customer engagement) }\end{array}$ & Brodie vd. (2011:260) \\
\hline & & $\begin{array}{l}\text { Çevrimiçi topluluklar bağlamında, bireyin bir çevrimiçi } \\
\text { toplulukla olan etkileşimlerine bilişsel, duygusal ve } \\
\text { davranışsal yatırımları (online community engagement) }\end{array}$ & $\begin{array}{l}\text { Nguyen, Conduit, Lu } \\
\text { ve Rao Hill (2016:244) }\end{array}$ \\
\hline & & $\begin{array}{l}\text { Aktörlerin hem ilginlik davranışı sergilemek üzere } \\
\text { gerçekleştirdikleri planları hem de bir hizmet ekosistemi } \\
\text { tarafından sağlanan kurumsal bağlamda etkileşimli bir kaynak } \\
\text { entegrasyonu sürecine ilgin olma faaliyetleri (actor } \\
\text { engagement) }\end{array}$ & $\begin{array}{l}\text { Storbacka, Brodie, } \\
\text { Böhmann, Maglio ve } \\
\text { Nenonen (2016:3009) }\end{array}$ \\
\hline & & $\begin{array}{l}\text { Aktörlerin hem ilginlik davranışı sergilemek üzere } \\
\text { gerçekleştirdikleri planları hem de etkileşimli bir kaynak } \\
\text { entegrasyonu sürecine ilgin olma faaliyetleri (multi-actor } \\
\text { engagement) }\end{array}$ & $\begin{array}{l}\text { Li, Cui ve Peng } \\
(2017: 738)\end{array}$ \\
\hline & & $\begin{array}{l}\text { Müşterilerin işletmeye doğrudan ve/veya dolaylı katkıları } \\
\text { yoluyla değer katma mekanizması (customer engagement) }\end{array}$ & $\begin{array}{l}\text { Pansari ve Kumar } \\
(2017: 295)\end{array}$ \\
\hline
\end{tabular}


Tablo 1. Müşteri Illginliğinin Tanımı ve Boyutları (Devamı)

\begin{tabular}{|c|c|c|c|}
\hline \multirow{4}{*}{$\begin{array}{l}\frac{y}{\overline{0}} \\
\frac{0}{0} \\
\frac{2}{2}\end{array}$} & \multirow{2}{*}{ 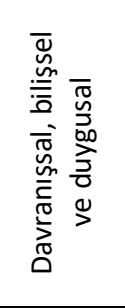 } & $\begin{array}{l}\text { Tüketicinin; diğer tüketiciler, pazarlama temsilcileri ve sosyal } \\
\text { medya marka toplulukları (SMBC) içindeki diğer ilgili taraflarla } \\
\text { olan etkileşim deneyimleriyle ilgili bilişsel, duygusal ve } \\
\text { davranışsal boyutlardan oluşan psikolojik durumu (consumer } \\
\text { engagement in an SMBC) }\end{array}$ & $\begin{array}{l}\text { Liu, Lee, Liu ve Chen } \\
(2018: 2)\end{array}$ \\
\hline & & $\begin{array}{l}\text { Belirli bir hizmet ekosistemindeki etkileşimli bir süreç } \\
\text { boyunca paydaş deneyimleri sayesinde ortaya çıkan psikolojik } \\
\text { durum (stakeholder engagement) }\end{array}$ & $\begin{array}{lr}\text { Jonas, } & \text { Boha, } \\
\text { Sörhammar } & \text { ve } \\
\text { Moeslein (2018:402) }\end{array}$ \\
\hline & 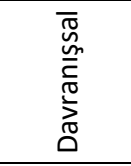 & $\begin{array}{l}\text { Topluluk üyelerinin, kendileri ve başkaları için değer yaratacak } \\
\text { şekilde başkalarına katılma ve onlarla iş birliği yapma } \\
\text { istekliliğini gösteren davranışlar bütünü (engagement in } \\
\text { virtual communities) }\end{array}$ & $\begin{array}{l}\text { Elise, Donthu, N., } \\
\text { Macelroy ve Wydra } \\
(2011: 83)\end{array}$ \\
\hline & 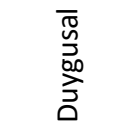 & $\begin{array}{l}\text { Çeşitli satın alma ve tüketici deneyimlerinden sonra bir } \\
\text { müşteri ile bir marka arasında ortaya çıkan proaktif, olumlu ve } \\
\text { duygusal psikolojik durum (customer engagement) }\end{array}$ & $\begin{array}{l}\text { Moliner } \\
(2018: 395)\end{array}$ \\
\hline \multirow{10}{*}{ 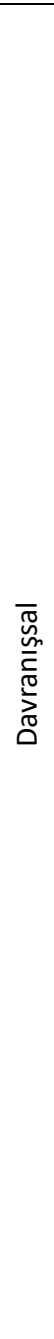 } & 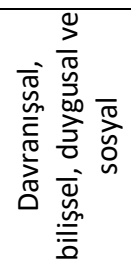 & $\begin{array}{l}\text { Müşterinin veya potansiyel müşterinin markanın/firmanın } \\
\text { teklifleri / faaliyetleriyle olan etkileşim ve bağlantı seviyesi } \\
\text { (customer engagement) }\end{array}$ & Vivek vd. (2014:406) \\
\hline & \multirow{4}{*}{ 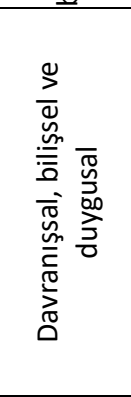 } & $\begin{array}{l}\text { Bireyin, belirli marka etkileşimlerine bilişsel, duygusal ve } \\
\text { davranışsal yatırım seviyesi (customer brand engagement) }\end{array}$ & Hollebeek (2011:565) \\
\hline & & $\begin{array}{l}\text { Tüketicilerin içeriğe özgü olan ve ilginlik odaklarına yönelik } \\
\text { bireysel eğilimlerini yansıtan durum (consumer engagement) }\end{array}$ & $\begin{array}{l}\text { Dessart, Veloutsou ve } \\
\text { Morgan-Thomas } \\
(2016: 409)\end{array}$ \\
\hline & & $\begin{array}{l}\text { Tüketicinin, belirli tüketici/marka etkileşimleri sırasında veya } \\
\text { bunlarla ilişkili olarak pozitif bilişsel, duygusal ve davranışsal } \\
\text { marka ile ilgili faaliyetleri (consumer brand engagement) }\end{array}$ & $\begin{array}{l}\text { Hollebeek, Glynn ve } \\
\text { Brodie (2014:10 }\end{array}$ \\
\hline & & $\begin{array}{l}\text { Müşterinin bir firmanın pazarlama işlevine finansal himayenin } \\
\text { ötesine geçen gönüllü kaynak katkısı (customer engagement) }\end{array}$ & $\begin{array}{l}\text { Harmeling } \\
(2017: 316)\end{array}$ \\
\hline & 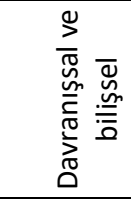 & $\begin{array}{l}\text { Tüketicinin bir şirketin sosyal medya faaliyetlerine aşinalığı ve } \\
\text { bu faaliyetleri çevrimiçi olarak takibi (Consumer engagement } \\
\text { in a company's social media activities) }\end{array}$ & $\begin{array}{l}\text { Dijkmans } \\
(2015: 62)\end{array}$ \\
\hline & & $\begin{array}{l}\text { Yalnızca ticari işlemlerle sınırlı olmayan, bunun ötesine geçen, } \\
\text { marka veya firma odaklı, satın almanın ötesinde ve } \\
\text { motivasyonel faktörlerle açığa çıkan müşteri dışavurumları } \\
\text { (customer engagement behavior) }\end{array}$ & $\begin{array}{l}\text { Van Doorn } \\
(2010: 254)\end{array}$ \\
\hline & $\begin{array}{l}\overline{\widetilde{n}} \\
\underline{\underline{n}}\end{array}$ & $\begin{array}{l}\text { Motivasyonel faktörlerle açığa çıkan, müşterinin marka veya } \\
\text { işletmeye karşı dışavurumları (customer engagement) }\end{array}$ & Kumar vd. (2010:298) \\
\hline & $\underset{\substack{\pi \\
\frac{\pi}{\pi}}}{\bar{\pi}}$ & $\begin{array}{l}\text { Bir markanın, ürünün veya firmanın teklifleri ve faaliyetlerine } \\
\text { karşı, kurulan etkileşimlerin ve çıkarımlarının yoğunluğu } \\
\text { yoluyla bir bağlılık tezahürü (engagement in Twitter) }\end{array}$ & $\begin{array}{l}\text { Muñoz-Expósito, } \\
\text { Oviedo-García ve } \\
\text { Castellanos-Verdugo } \\
(2017: 1128)\end{array}$ \\
\hline & & $\begin{array}{l}\text { Tüketicilerin katkı sağlayıcı davranışları, topluluklara } \\
\text { prososyal katkıları (consumer engagement in online brand } \\
\text { communities) }\end{array}$ & $\begin{array}{l}\text { Wu, Fan ve Zhao } \\
(2018: 259)\end{array}$ \\
\hline
\end{tabular}

Müşteri ilginliği kapsamında incelenmesi gereken konulardan biri de müşteri ilginliğinin kimler arasında gerçekleştiği, müşteri ilginliğine hangi tarafların katıldığıdır. 2016 yılına kadar yapılan çalışmalarda, müşteri ilginliğinin işletme- müşteri bağlamında incelendiği görülmektedir. Vargo ve Lusch (2016)'ın hizmet baskın mantık yaklaşımına daha makro bir perspektifle bakarak diğer tüm aktörlerin (çalışan, tedarikçi, üretici vb.) değer yaratma sürecine dahil olması gerekliliğini vurgulamaları üzerine, müşteri ilginliği kavramı da bu yeni yaklaşımdan etkilenmiştir. Böylelikle müşteri ilginliği tanımları ve kapsamı yeniden gözden geçirilmiştir. 
Ilk olarak Hollebeek vd. (2016), Bordie vd. (2011)'nin yaklaşımlarını hizmet baskın mantıktaki yeni gelişmeler çerçevesinde genişletmişler ve müşteri ilginliğini, müşterinin motivasyon odaklı gerçekleşen, temel işleyen (bilişsel, duygusal, davranışsal ve sosyal bilgi birikimi ve yetenekler vb.) ve işlenen kaynaklara (örn. ekipman) hizmet sistemlerindeki marka etkileşimlerine yönelik gönüllü yatırımı olarak tanımlamışlardır. Müşteri ilginliği, bu gelişmeleri takiben, bütüncül aktör ilginliğinin özel bir biçimi olarak görülmeye başlanmıştır (Storbacka vd., 2016). Kavram üzerine tartışmalar, sürece katılan diğer tarafları içerecek şekilde de devam etmiştir. Örneğin Kumar vd. (2010) müşteri ilginliğini, Van Doorn vd. (2010)'ni takiben, motivasyonel faktörlerle açığa çıkan, müşterinin marka veya işletmeye karşı dışavurumları olarak tanımlamaktadırlar ve bu davranışın, müşteri firmadan bir satın alım gerçekleştirmeden tamamlanamayacak bir süreç olduğunu vurgulamaktadırlar. Bu müşteri - işletme bağlamındaki yaklaşımdan yaklaşık altı yıl sonra, içerisinde Kumar'ın da bulunduğu bir çalışmada (Kumar ve Pansari, 2016), müşteri ilginliğine makro perspektifle yaklaşıldığı dikkat çekmektedir. Bu çalışmada, müşteri ilginliği kavramına işletme çalışanları da dahil edilmiş, kavramsallaştırma çalışmaları müşteri-işletme-çalışan bağlamında genişletilmiştir (Kumar ve Pansari, 2016).

\section{Metodoloji}

Bu çalışmada, Web of Science (WOS) veri tabanı vasıtasıyla bir literatür taraması gerçekleştirilmiştir. Yapılan ön incelemede müşteri ilginliğinin; işletme, pazarlama, bilgisayar mühendisliği, iletişim, elektrik/elektronik mühendisliği, finans, sağlık gibi birçok farklı alanda çalışıldığı görülmüştür. Bu çok yönlü kavramın genel bir çerçevesini çizebilmek adına hem farklı disiplinleri bünyesinde barındıran hem de etki düzeyi yüksek ve kaliteli çalışmaların yer aldığı WOS veritabanını seçilmiştir. Elde edilecek verinin "müşteri ilginliği" ile olan alaka düzeyini artırmak için bu veritabanının arama motoru özelliği kullanılmış, başlık veya ana konu bölümlerinde "customer engagement" veya "consumer engagament" terimi geçen makaleler 2019 yılının Nisan ayında filtrelenerek 490 adet makaleye ulaşılmıştır.

Çalışmada ilk olarak, 490 adet makale incelenerek çeşitli kriterlere göre tasnif edilmiştir. İkinci aşamada ise; çalışma alanı, çalışma konusu, yöntem, teorik kapsam, öncüller, ardıllar gibi odaklarla derinlemesine incelenmiştir. Bu incelemenin ardından 93 makale, müşteri ilginliği terimini başlık veya gövdesinde içermesine rağmen bağlam olarak temel odağı müşteri ilginliği olmadığından konuyu aydınlatmada yetersiz kaldığı ve bu çalışmadaki müşteri ilginliğini aydınlatma odağı ile yeterince alakalı görülmediği için elenmiştir (Şekil 1). İlgili makalelerin incelenmesi için, içerik analizi yönteminden faydalanılmıştır (Yıldırım ve Şimşek, 2011). Makaleler, müşteri ilginliği kavramına yaklaşımları bakımından bu yöntemle tasnif edilmiş ve bu makalelerin, ilişkisel anlamda kavrama yönelik nasıl bir bütün oluşturduğuna dair bir inceleme gerçekleştirilmiştir.

Şekil 1. Literatür İncelemesi Süreci

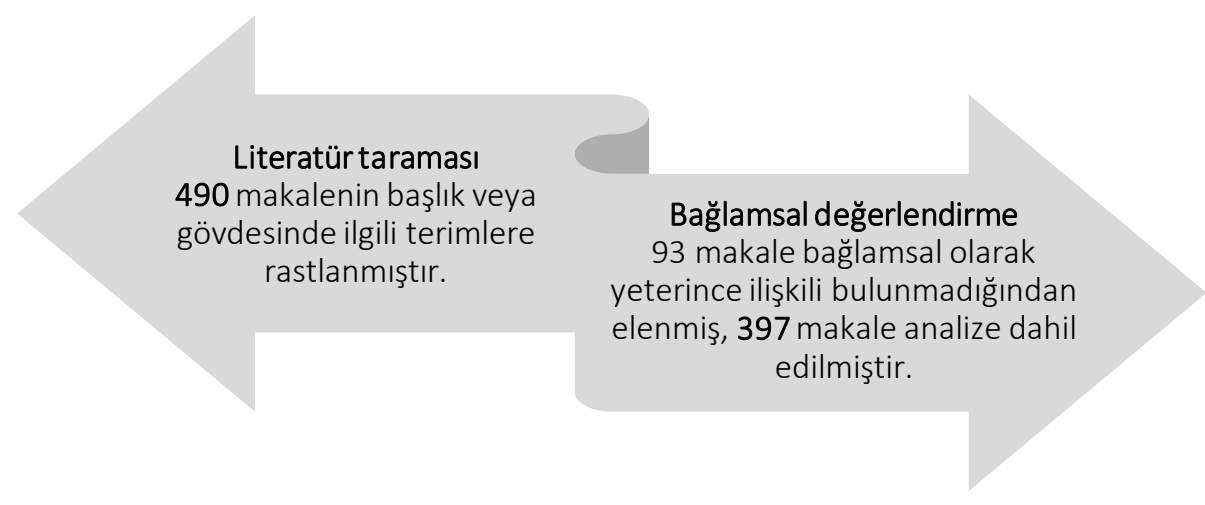

Ek olarak, ilgili makalelerin özelliklerini sunmak üzere yıl ve dergi bazında bir bibliyometrik analiz gerçekleştirilmiştir. 397 makalenin yıllara göre dağı̆ımı incelendiğinde, konunun son yıllardaki popülaritesi dikkat çekmektedir (Şekil 2). Çalışmanın gerçekleştirildiği zaman diliminde, 2019 yılının yalnızca ilk üç ayına ait makaleler incelenebilmiştir ve araştırmaya dahil edilebilir yalnızca bir makaleye rastlanmıştır. Bu çalışma, 
yılık dağııımı net şekilde görebilmek adına Şekil 2'de gösterilmemiştir. Çalışma sayıları incelendiğinde, literatürdeki müşteri ilginliği kavramına olan ilginin 2010 yılından itibaren anlamlı bir ivme kazandığı ve her yıl da önemli bir oranda arttığı görülmektedir.

Şekil 2. Müşteri ilginliğiyle Illgili Makalelerin Yıllara Göre Dağılımı

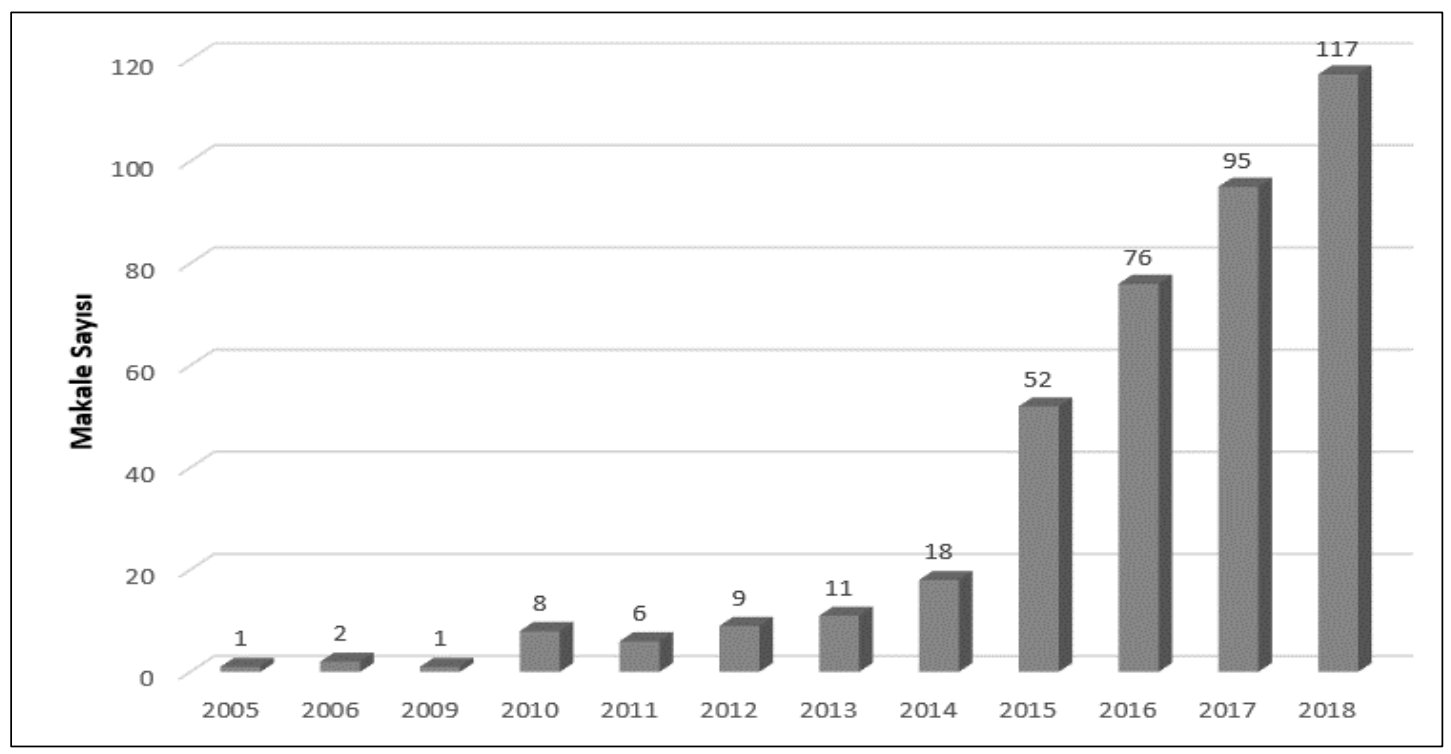

Çalışma kapsamında, makalelerin dergi dağııımları da incelenmiştir ve bir dergide birden fazla kez müşteri ilginliğine yönelik çalışma yayınlanan dergiler Tablo 2' de gösterilmiştir. Tabloda da görülebileceği gi bi, konunun en çok ilgi gördüğü dergiler sırasıyla Journal of Services Marketing (24), Journal of Service Management (22), International Journal of Contemporary Hospitality Management (14), Journal of Business Research (13), Journal of Service Theory and Practice (12), Computers in Human Behavior (10), Journal of Service Research (10) şeklindedir.

Tablo 2. Müşteri İlginliğiyle İlgili Makalelerin Yayınlandıkları Dergilere Göre Dağılımı

\begin{tabular}{|l|c|l|c|}
\hline Dergi & $\begin{array}{c}\text { Makale } \\
\text { Sayısı }\end{array}$ & Dergi & $\begin{array}{c}\text { Makale } \\
\text { Sayısı }\end{array}$ \\
\hline Journal of Services Marketing & 24 & $\begin{array}{l}\text { Inzinerine Ekonomika-Engineering } \\
\text { Economics }\end{array}$ & 3 \\
\hline Journal of Service Management & 22 & Journal of Brand Management & 3 \\
\hline $\begin{array}{l}\text { Int. Journal of Contemporary Hospitality } \\
\text { Management }\end{array}$ & 14 & Journal of Internet Commerce & 3 \\
\hline Journal of Business Research & 13 & Journal of Marketing Theory and Practice & 3 \\
\hline Journal of Service Theory and Practice & 12 & Renewable \& Sustainable Energy Reviews & 3 \\
\hline Computers in Human Behavior & 10 & Asia Pacific Journal of Tourism Research & 2 \\
\hline Journal of Service Research & 10 & Corporate Communications & 2 \\
\hline Tourism Management & 9 & Electronic Markets & 2 \\
\hline Journal of Retailing and Consumer Services & 8 & European Journal of Marketing & 2 \\
\hline Journal of Marketing Management & 7 & Frontiers in Psychology & 2 \\
\hline Online Information Review & 7 & Harvard Business Review & 2 \\
\hline $\begin{array}{l}\text { Electronic Commerce Research and } \\
\text { Applications }\end{array}$ & 6 & Information Systems Frontiers & 2 \\
\hline $\begin{array}{l}\text { Journal of The Academy of Marketing } \\
\text { Science }\end{array}$ & 6 & $\begin{array}{l}\text { Int. Journal of Advanced Computer Science } \\
\text { and Applications }\end{array}$ & 2 \\
\hline Telematics and Informatics & 6 & International Journal of Bank Marketing & 2 \\
\hline Business Horizons & 5 & $\begin{array}{l}\text { Int. Journal of Information Systems in The } \\
\text { Service Sector }\end{array}$ & 2 \\
\hline
\end{tabular}


N. Cavdar Aksoy - E. Tumer Kabadayı - A. Kocak Alan - C. Ermehan

Tablo 2. Müşteri İlginliğiyle İlgili Makalelerin Yayınlandıkları Dergilere Göre Dağılımı (Devamı)

\begin{tabular}{|l|c|l|c|}
\hline $\begin{array}{l}\text { Int. Journal of Retail \& Distribution } \\
\text { Management }\end{array}$ & 5 & $\begin{array}{l}\text { International Journal of Management and } \\
\text { Economics }\end{array}$ & 2 \\
\hline Journal of Interactive Marketing & 5 & International Journal of Market Research & 2 \\
\hline Journal of Product and Brand Management & 5 & $\begin{array}{l}\text { International Journal of Operations \& } \\
\text { Production Management }\end{array}$ & 2 \\
\hline Marketing Intelligence \& Planning & 5 & $\begin{array}{l}\text { International Journal of Research in } \\
\text { Marketing }\end{array}$ & 2 \\
\hline Int. Journal of Information Management & 4 & Journal of Advertising & 2 \\
\hline Internet Research & 4 & $\begin{array}{l}\text { Journal of Fashion Marketing and } \\
\text { Management }\end{array}$ & 2 \\
\hline Journal of Communication Management & 4 & Journal of Marketing for Higher Education & 2 \\
\hline $\begin{array}{l}\text { Journal of Hospitality and Tourism } \\
\text { Technology }\end{array}$ & 4 & Journal of Operations Management & 2 \\
\hline Journal of Marketing & 4 & Journal of Retailing & 2 \\
\hline Journal of Research in Interactive Marketing & 4 & Journal of Travel Research & 2 \\
\hline Psychology \& Marketing & 4 & Management Decision & 2 \\
\hline Utilities Policy & 4 & Management Science & 2 \\
\hline Industrial Marketing Management & 3 & Managing Service Quality & 2 \\
\hline $\begin{array}{l}\text { International Journal of Electronic } \\
\text { Commerce }\end{array}$ & 3 & Mis Quarterly Executive & 2 \\
\hline Int. Journal of Hospitality Management & 3 & Service Business & 2 \\
\hline Int. Journal of Quality and Service Sciences & 3 & Service Industries Journal & 2 \\
\hline
\end{tabular}

\section{Bulgular}

\section{1. İncelenen Konular Bakımından Müşteri İlginliği}

Çalışma kapsamında ele alınan 397 makale, makalelerin odak noktaları dikkate alınarak altı gruba ayrılmıştır. Bunu yaparken, makalelerin konumlandırmaları dikkatlice incelenmiştir. Araştırmacıların vurgulamış oldukları, çalışmalarının amaçları ve katkıları bağlamında bir gruplandırma yapılmıştır. Gruplandırma kategorileri; makalelerin temel amaçlarını ve çalışma neticesinde ortaya çıkan katkılarını takiben, müşteri ilginliği kavramının teorik geçmişini inceleyen makaleler (Teori), kavrama özgü strateji geliştirme çabalarını içeren makaleler (Strateji), kavramı pazarlama uygulamaları bağlamında inceleyen makaleler (ilginlik Uygulama Alanları), kavramının davranışsal (Davranışsal Boyut), duygusal (Duygusal Boyut) veya bilişsel boyutunu (Bilişsel Boyut) inceleyen makaleler şeklindedir. Tablo 3, her bir gruba özgü alt konuları ve ilgili makalelerin sayısını göstermektedir. Teori grubunda 66 makale, Strateji grubunda 108 makale, ilginlik Uygulama Alanları grubunda 139 makale, Davranışsal Bakış Açısı grubunda 75 makale, Duygusal Bakış Açısı grubunda 8 makale olduğu, Bilişsel Bakış Açısı grubunda ise 1 makalenin yer aldığı görülmektedir. Çalışmalar yöntem bakımından incelendiğinde ise, bu 397 makaleden $248^{\prime}$ inin nicel, 74'ünün nitel ve 75'inin de teorik kavramsal çalışmalar olduğu görülmüştür.

Tablo 3. Illginlik Kavramına İlişkin Yaklaşımlar ve İncelenen Konular

\begin{tabular}{|l|l|c|}
\hline Yaklaşım & Konu & $\begin{array}{c}\text { Makale } \\
\text { sayısı }\end{array}$ \\
\hline \multirow{4}{*}{ Teori } & Kavramsallaştırma çalışmaları & 52 \\
\cline { 2 - 3 } & Literatür incelemeleri & 12 \\
\hline \multirow{5}{*}{ Strateji } & Müşteri ilginliği süreci & 36 \\
\cline { 2 - 3 } & Sosyal medya platformlarında müşteri ilginliği & 22 \\
\cline { 2 - 3 } & Firmaların sosyal medya kullanımı & 14 \\
\cline { 2 - 3 } & Müşteri ilginliği değeri & 6 \\
\cline { 2 - 3 } & Müşteri ilginliğinin negatif yönü & 4 \\
\cline { 2 - 3 } & Sadakat geliştiren faktörlerin incelenmesi & 4 \\
\cline { 2 - 3 } & Müşteri ilginliğinde çalışanların rolleri ve önemi & 3 \\
\cline { 2 - 3 } & Müşteri ilginliği analitiği & \\
\hline
\end{tabular}


Tablo 3. Illginlik Kavramına Illişkin Yaklaşımlar ve İncelenen Konular (Devamı)

\begin{tabular}{|c|c|c|}
\hline \multirow{9}{*}{ Strateji } & Müşterilerin sosyal medya kullanımı & 3 \\
\hline & Çevrimiçi ağızdan ağıza pazarlama ve müşteri ilginliği & 2 \\
\hline & Müşteri ilginliği döngüsü & 2 \\
\hline & Müşteri ilginliğine engel teşkil eden bariyerlerin incelenmesi & 2 \\
\hline & Yeni ürün geliştirme faaliyetleri için müşteri ilginliği çalışmaları & 2 \\
\hline & Pazarlama stratejisi ve müşteri ilginliği & 1 \\
\hline & Hizmet değer ağları & 1 \\
\hline & Kurumsal itibar & 1 \\
\hline & Müşteri ilginliği ve yeni ürün benimsetme çalışmaları & 1 \\
\hline \multirow{18}{*}{$\begin{array}{l}\text { İlginlik } \\
\text { uygulama } \\
\text { alanları }\end{array}$} & Çevrimiçi marka topluluklarının müşteri ilginliği & 26 \\
\hline & Sosyal medya uygulamaları & 21 \\
\hline & Mobil uygulamalarda müşteri ilginliği & 14 \\
\hline & Müşteri ilişkileri yönetiminde müşteri ilginliği & 12 \\
\hline & Aktör ilginliği & 10 \\
\hline & Enerji yönetim uygulamalarında müşteri ilginliği & 8 \\
\hline & Çevrimiçi marka ilginliği uygulamaları & 7 \\
\hline & Müşteri ilginliği ekosisteminin kurulması & 7 \\
\hline & Su kaynakları yönetiminde müşteri ilginliği uygulamaları & 7 \\
\hline & Spor pazarlamasında müşteri ilginliği & 6 \\
\hline & İnternet sitesi - bloglar bazında uygulamalar & 6 \\
\hline & Müşteri ilginliği için büyük veri analiz uygulamaları & 4 \\
\hline & Sağlık sektöründe müşteri ilginliği uygulamaları & 4 \\
\hline & B2B bağlamında müşteri ilginliği uygulamaları & 2 \\
\hline & Çevrimiçi oyunların müşteri ilginliğine katkısını inceleyen çalışmalar & 2 \\
\hline & Çevrimiçi satış uygulamaları & 1 \\
\hline & Eğitimde öğrenci ilginliği uygulamaları & 1 \\
\hline & Sponsorluğun müşteri ilginliği üzerindeki katkısını inceleme & 1 \\
\hline \multirow{7}{*}{$\begin{array}{l}\text { Davranışsal } \\
\text { boyut }\end{array}$} & Müşteri ilginliği davranışları & 23 \\
\hline & Birlikte değer yaratma & 21 \\
\hline & Müşterilerin marka ilginlik davranışları & 15 \\
\hline & Müşterilerin davranışlarını değiştiren faktörleri inceleyen çalışmalar & 9 \\
\hline & Oyun ile müşteri ilginliği davranışı oluşturma & 4 \\
\hline & Kurumsal sosyal sorumluluk ve müşteri ilginliği davranışları & 2 \\
\hline & Müşteriler tarafından yürütülen reklam faaliyetleri & 1 \\
\hline \multirow{4}{*}{$\begin{array}{l}\text { Duygusal } \\
\text { boyut }\end{array}$} & Ürün / hizmete karşı geliştirilen tutumlar & 4 \\
\hline & Organizasyonlara karşı geliştirilen tutumlar & 2 \\
\hline & Markaya karşı geliştirilen tutumlar & 1 \\
\hline & Duyguların müşteri ilginliğine etkisini inceleyen çalışmalar & 1 \\
\hline $\begin{array}{l}\text { Bilişsel } \\
\text { boyut }\end{array}$ & Müşteri ilginliğinin bilişsel boyutu & 1 \\
\hline
\end{tabular}

Müşteri ilginliği konusunun teorik dayanağını sunmak üzere yürütülen çalışmalarda araştırmacılar, müşteri ilginliğine yönelik bir çerçeve oluşturarak gelecek araştırmacılara yön vermeye çalışmıştır. Çalışmada incelenen bu tür makalelerde, iki yöntem izlenmiştir. Kimi çalışmalar bir literatür özeti sunma yolunu tercih ederken (örn. Verhoef, Reinartz ve Krafft, 2010; Busalim ve Hussin, 2016; Islam ve Rahman, 2016; Graffigna, 2017; King, 2017; Busalim, Hussin ve lahad, 2019) kimileri müşteri ilginliğini kavramsallaştırmak üzere incelemeler (örn. van Doorn vd., 2010; Brodie vd., 2011; Bowden, Gabbott ve Naumann, 2015; Chandler ve Lusch, 2015; Maslowska, Malthouse ve Collinger, 2016; Storbacka vd., 2016; Harmeling vd., 2017; Pansari ve Kumar, 2017; Gupta, Pansari ve Kumar, 2018; Youssef, Johnston, AbdelHamid, Dakrory ve Seddick, 2018) gerçekleştirmiştir.

Strateji geliştirme odaklı çalışmalarda, işletmelere bir yol haritası sunmak üzere, müşteri ilginliğinin oluşum süreci ve işleyişi üzerinde durulmuştur. Çalışmada incelenen strateji odaklı makalelerin büyük bir kısmını, müşteri ilginliğini bir süreç olarak ele alıp nasıl açığa çıktığını anlama çalışmaları oluşturmaktadır ve böylelikle bu çalışmalar, müşteri ilginliği konusunda strateji geliştirme çabasında olan taraflarca bir kaynak olarak görülebilir (örn. Elise vd., 2010; Cambra vd., 2012; Gambetti, Graffigna ve Biraghi, 2012; Röndell, 
Sörhammar ve Gidhagen, 2016; Chahal ve Rani, 2017; Hapsari, Clemes ve Dean, 2017; Lei, Pratt ve Wang, 2017; Carlson, Rahman, Voola ve De Vries, 2018; Romero, 2018). Sosyal medya platformlarında müşteri ilginliğini anlamaya yönelik olarak yürütülen çalışmalar da strateji geliştirme odağı kapsamında incelenmiştir. Bu çalışmalardan bazılarında, müşteri ilginliği sosyal medya bağlamında müşteri perspektifinden ele alınmış (örn. Khobzi ve Teimourpour, 2015; Geissinger ve Laurell, 2016; Clark, Black ve Judson, 2017; Gutiérrez-Cillán, Camarero-Izquierdo ve San José-Cabezudo, 2017; Ibrahim, Wang ve Bourne, 2017; 2018; Gupta vd., 2018; Gvili ve Levy, 2018; Lin, Yang, Ma ve Huang, 2018; Osei-Frimpong ve McLean, 2018; Simon ve Tossan, 2018; Syrdal ve Briggs, 2018; Triantafillidou ve Siomkos, 2018), bazılarında ise, firmaların ilginlik oluşturmak üzere sosyal medyada nasıl var olması, sosyal medyayı nasıl kullanmaları gerektiği tartışılmıştır (örn. Pongpaew, Speece ve Tiangsoongnern, 2017; Bianchi ve Andrews, 2018; Pawsey, Nayeem ve Huang, 2018; Viswanathan, Malthouse, Maslowska, Hoornaert ve Van den Poel, 2018). Bu grupta ele alınan alt konulardan bir diğeri de, stratejik bir bakış açısını yansıtan, müşteri ilginliğinin firmaya kattığı kısa vadeli ve uzun vadeli değerlerdir (örn. Marbach, Lages ve Nunan, 2016; Kumar, 2017).

Çevrimiçi marka toplulukları (Aksoy vd., 2013; Chuang ve Chen, 2015; Shahrokh ve Poursaeed, 2015; Verhagen, Swen, Feldberg ve Merikivi, 2015; Bowden, Conduit, Hollebeek, Luoma-aho ve Solem, 2017; Ibrahim vd., 2017; Islam ve Rahman, 2017; Islam vd., 2018; Jani, Hafiz, Maksom, Shariff ve Mustapha, 2018), mobil uygulamalar (Dovaliené, Piligrimienè ve Masiulytė, 2016; Wijland, Hansen ve Gardezi, 2016; Fang, 2017; Fang, Zhao, Wen ve Wang, 2017; Zhang, Lu ve Kizildag, 2017), müşteri ilişkileri yönetimi (Potra, Izvercian ve Miclea, 2016; So, King, Sparks ve Wang, 2016; Marino ve Lo Presti, 2018), enerji (Littlechild, 2016; Stephens, Kopin, Wilson ve Peterson, 2017; AlSkaif, Lampropoulos, Ivan den Broek ve van Sark, 2018; Ponds, Arefi, Sayigh ve Ledwich, 2018), su (Hendry, 2016; Heims ve Lodge, 2018; Pawsey vd., 2018), spor (Yoshida, Gordon, Nakazawa ve Biscaia, 2014; Stander ve De Beer, 2016; Stander, Van Zyl ve Motaung, 2016), eğitim (Pittaway, 2016) ve büyük veri (Orenga-Roglá ve Chalmeta, 2016; Li, Juric ve Brodie, 2017; Lee, Hosanagar ve Nair, 2018) gibi alanlarda müşteri ilginliği üzerine yürütülmüş ve belirli bağlamları yansıtan çalışmalar dikkat çekmektedir. Bu çalışmalar, ilginliğin belirli bir alan bazında tartışıldığı çalışmalardır ve bu sebeple ilginlik Uygulama Alanları grubu altında ele alınmıştır.

Müşteri ilginliğinin; davranışsal (Jaakkola ve Alexander, 2014; Braun, Batt, Bruhn ve Hadwich, 2016; Groeger, Moroko ve Hollebeek, 2016; Guo, Zhang ve Wang, 2016; Robinson ve Celuch, 2016; Chen, Yu, Gentry, ve Yu, 2017; Risitano, Romano, Sorrentino ve Quintano, 2017; Wei, Hua, Fu ve Guchait, 2017; Roy, Balaji, Soutar, Lassar ve Roy, 2018a; Roy, Shekhar, Lassar ve Chen, 2018b; Wu vd., 2018), duygusal (Boardman, Raciti ve Lawley, 2016; Arya vd., 2018) ve bilişsel (Tu vd., 2018) boyutu bakımından incelendiği çeşitli çalışmalar da literatürde karşılaşılan konuyu ele alış bakımından diğer ilginlik alt alanlarını oluşturmaktadır.

\subsection{Kullanılan Teorik Yaklaşımlar Bakımından Müşteri Illginliği}

Çalışma kapsamında yapılan incelemede, müşteri ilginliğinin birçok teori perspektifinde incelendiği görülmüştür (Tablo 4). Incelenen makalelerde; Hizmet Baskın Mantık (57), Kullanımlar ve Doyumlar Teorisi (21), ilişkisel Pazarlama Teorisi (21), Sosyal Mübadele Teorisi (19) ve Sosyal Kimlik Teorisi'nin (14) yoğunlukla kullanıldığı görülmektedir.

Müşteri ilginliği konusunu açıklamak üzere kullanılan öne çıkan teorik dayanaklar incelendiğinde, en sık faydalanılan teorik dayanağın "hizmet baskın mantık" (Vargo ve Lusch, 2004) olduğu görülmektedir. Müşteri ilginliği kavramındaki anlayışa paralel olarak, hizmet baskın mantıkta nihai ürün yoktur, üretilen bir üründen tüm katılımcılar değer elde edebilmektedir. Nihai değeri alan kullanıcıdan ilk tedarikçiye kadar herkes, bu değer sürecini talepleri ile yönlendirmektedir. Hizmet baskın mantık, müşteriler de içerisinde olmak üzere tüm tarafları değer yaratma sürecine bir aktör olarak dahil etmektedir. Müşterinin katkısını destekleyen bu teori müşteri ilginliğine çok iyi bir zemin hazırladığından (Brodie vd., 2011), müşteri ilginliği literatüründe sıklıkla kullanılmıştır (Gebauer, Johnson ve Enquist, 2010; Chathoth vd., 2014; Jaakkola ve Alexander, 2014; Van Eijk ve Steen, 2014; Chandler ve Lusch, 2015; Chuang ve Chen, 2015; Bitter ve GrabnerKräuter, 2016; Chathoth, Ungson, Harrington ve Chan, 2016; Groeger vd., 2016; Ramaswamy ve Ozcan, 2016; Sharma ve Conduit, 2016; Clark vd.., 2017; Johnson ve Neuhofer, 2017; Storbacka vd., 2016) 
Tablo 4. Müşteri IIIginliği - Teorik Kapsam

\begin{tabular}{|c|c|c|c|}
\hline Teori & $\begin{array}{c}\text { Makale } \\
\text { Sayısı }\end{array}$ & Teori & $\begin{array}{c}\text { Makale } \\
\text { Sayısı }\end{array}$ \\
\hline $\begin{array}{l}\text { Hizmet Baskın Mantık } \\
\text { (Service Dominant Logic) }\end{array}$ & 57 & \begin{tabular}{|l} 
Benlik Algısı Teorisi \\
(Self Perception Theory)
\end{tabular} & 2 \\
\hline $\begin{array}{l}\text { Kullanımlar ve Doyumlar Teorisi } \\
\text { (Uses And Gratification Theory) }\end{array}$ & 21 & $\begin{array}{l}\text { Yakın İlişkiler Teorisi } \\
\text { (Theory of Close Relationships) }\end{array}$ & 2 \\
\hline $\begin{array}{l}\text { İlişkisel Pazarlama Teorisi } \\
\text { (Relationship Marketing Theory) }\end{array}$ & 21 & $\begin{array}{l}\text { iletişimsel Eylem Teorisi } \\
\text { (Theory of Communicative Action) }\end{array}$ & 1 \\
\hline $\begin{array}{l}\text { Sosyal Mübadele Teorisi } \\
\text { (Social Exchange Theory) }\end{array}$ & 19 & $\begin{array}{l}\text { Etkileşimsel Psikoloji Teorisi } \\
\text { (Interactional Psychology Theory) }\end{array}$ & 1 \\
\hline $\begin{array}{l}\text { Sosyal Kimlik Teorisi } \\
\text { (Social Identity Theory) }\end{array}$ & 14 & \begin{tabular}{|l|} 
Sembolik Tüketim Teorisi \\
(Symbolic Consumption Theory) \\
\end{tabular} & 1 \\
\hline $\begin{array}{l}\text { Gömülü Teori } \\
\text { (Grounded Theory) }\end{array}$ & 10 & $\begin{array}{l}\text { iş Tasarımı Teorisi } \\
\text { (Theory of Job Design) }\end{array}$ & 1 \\
\hline $\begin{array}{l}\text { Planlanlanmış Davranış Teorisi } \\
\text { (Theory of Planned Behaviour) }\end{array}$ & 9 & $\begin{array}{l}\text { Alışkanlık Teorisi } \\
\text { (Habituation Theory) }\end{array}$ & 1 \\
\hline $\begin{array}{l}\text { Uyaran - Organizma - Tepki Modeli } \\
\text { (Stimulus - Organism - Response Model) }\end{array}$ & 8 & \begin{tabular}{|l|} 
Toplumsal Hareket Teorisi \\
(Social Movement Theory)
\end{tabular} & 1 \\
\hline $\begin{array}{l}\text { Müşteri İlginliği Teorisi } \\
\text { (Customer Engagement Theory) }\end{array}$ & 8 & \begin{tabular}{|l|} 
Toplumsal Nüfuz Teorisi \\
(Social Penetration Theory)
\end{tabular} & 1 \\
\hline $\begin{array}{l}\text { Ilginlik Teorisi } \\
\text { (Engagement Theory) }\end{array}$ & 8 & $\begin{array}{l}\text { Kolektif Eylem Teorisi } \\
\text { (Collective Action Theory) } \\
\end{array}$ & 1 \\
\hline $\begin{array}{l}\text { Gerekçeli Eylem Teorisi } \\
\text { (Theory of Reasoned Action) }\end{array}$ & 7 & \begin{tabular}{|l|} 
Beş Büyük Kişilik Özelliği Modeli \\
(Big Five Personality Traits Model)
\end{tabular} & 1 \\
\hline $\begin{array}{l}\text { Sosyal - Bilişsel Teori ve Akış Teorisi } \\
\text { (Social Cognitive and Flow Theory) }\end{array}$ & 6 & $\begin{array}{l}\text { Hizmet Kapsam Teorisi } \\
\text { (Servicescapes Theory) } \\
\end{array}$ & 1 \\
\hline $\begin{array}{l}\text { Kaynak Mübadele Teorisi } \\
\text { (Resource Exchange Theory) }\end{array}$ & 5 & \begin{tabular}{|l|} 
Hediye Verme Teorisi \\
(Gift Giving Theory) \\
\end{tabular} & 1 \\
\hline $\begin{array}{l}\text { Sosyal Bulunuşluk Teorisi } \\
\text { (Social Presence Theory) }\end{array}$ & 5 & \begin{tabular}{|l} 
Gözleme Dayalı Öğrenme Teorisi \\
(Observational Learning Theory)
\end{tabular} & 1 \\
\hline $\begin{array}{l}\text { Birleştirilmiş Teknoloji Kabul ve Kullanımı } \\
\text { Modeli } \\
\text { (Unified Theory of Acceptance and Use of } \\
\text { Technology) }\end{array}$ & 5 & $\begin{array}{l}\text { Beklenti Teorisi } \\
\text { (Prospect Theory) }\end{array}$ & 1 \\
\hline $\begin{array}{l}\text { Teknoloji Kabul Modeli } \\
\text { (Technology Acceptance Model) }\end{array}$ & 5 & \begin{tabular}{|l|} 
Hiyerarşik Model \\
(Hierarchy Model) \\
\end{tabular} & 1 \\
\hline $\begin{array}{l}\text { Yeniliğin Yayılması Teorisi } \\
\text { (Innovation Diffusion Theory) }\end{array}$ & 4 & \begin{tabular}{|l|} 
Hizmet Deneyimleri Teorisi \\
(Services Experience Theory)
\end{tabular} & 1 \\
\hline $\begin{array}{l}\text { Paydaş Teorisi } \\
\text { (Stakeholder Theory) }\end{array}$ & 4 & $\begin{array}{l}\text { Eğlence Teorisi } \\
\text { (The Fun Theory) } \\
\end{array}$ & 1 \\
\hline $\begin{array}{l}\text { Sosyal Etki Teorisi } \\
\text { (Social Influence Theory) }\end{array}$ & 4 & $\begin{array}{l}\text { Güven Aktarım Teorisi } \\
\text { (Trust Transfer Theory) }\end{array}$ & 1 \\
\hline $\begin{array}{l}\text { Tüketici Kültürü Teorisi } \\
\text { (Consumer Culture Theory) }\end{array}$ & 3 & \begin{tabular}{|l|} 
Modülerlik Teorisi \\
(Modularity Theory)
\end{tabular} & 1 \\
\hline $\begin{array}{l}\text { Onaylama - Onaylamama Teorisi } \\
\text { (Confirmation - Disconfirmation Theory) }\end{array}$ & 3 & $\begin{array}{l}\text { Faydacı Ve Hedonik Değer Yaklaşımı } \\
\text { (Utilitarian and Hedonic Value Approach) }\end{array}$ & 1 \\
\hline $\begin{array}{l}\text { Fayda Teorisi } \\
\text { (Utility Theory) }\end{array}$ & 3 & \begin{tabular}{|l|} 
Beklenti - Değer Teorisi \\
(Expectancy - Value Theory)
\end{tabular} & 1 \\
\hline $\begin{array}{l}\text { Öz Benlik Uyumu Teorisi } \\
\text { (Self - Congruity Theory) }\end{array}$ & 3 & \begin{tabular}{|l|} 
Yaratıcılık Teorisi \\
(Creativity Theory) \\
\end{tabular} & 1 \\
\hline $\begin{array}{l}\text { Karşılıklılık Teorisi } \\
\text { (Reciprocity Theory) }\end{array}$ & 3 & $\begin{array}{l}\text { Müşteri Merkezli Teori } \\
\text { (Customer Centric Theory) }\end{array}$ & 1 \\
\hline $\begin{array}{l}\text { Öz Belirleme Teorisi } \\
\text { (Self Determination Theory) }\end{array}$ & 3 & \begin{tabular}{|l|} 
Iletişimsel Ekoloji Teorisi \\
(Communicative Ecology Theory) \\
\end{tabular} & 1 \\
\hline $\begin{array}{l}\text { Yapılanma Teorisi } \\
\text { (Structuration Theory) }\end{array}$ & 3 & $\begin{array}{l}\text { Oyun Teorisi } \\
\text { (Game Theory) }\end{array}$ & 1 \\
\hline $\begin{array}{l}\text { Motivasyon Teorileri } \\
\text { (Theories of Motivation) }\end{array}$ & 3 & $\begin{array}{l}\text { ilgilenim Teorisi } \\
\text { (Involvement Theory) } \\
\end{array}$ & 1 \\
\hline
\end{tabular}


N. Cavdar Aksoy - E. Tumer Kabadayı - A. Kocak Alan - C. Ermehan

Tablo 4. Müşteri İlginliği - Teorik Kapsam (Devamı)

\begin{tabular}{|c|c|c|c|}
\hline Teori & $\begin{array}{l}\text { Makale } \\
\text { Sayısı }\end{array}$ & Teori & $\begin{array}{l}\text { Makale } \\
\text { Sayısı }\end{array}$ \\
\hline $\begin{array}{l}\text { Reklam Teorisi } \\
\text { (Advertising Theory) }\end{array}$ & 2 & $\begin{array}{l}\text { Belirsizliği Azaltma Teorisi } \\
\text { (Uncertainty Reduction Theory) }\end{array}$ & 1 \\
\hline $\begin{array}{l}\text { Karmaşıklık Teorisi } \\
\text { (Complexity Theory) }\end{array}$ & 2 & $\begin{array}{l}\text { Sosyal Kanıt Teorisi } \\
\text { (Social Proof Theory) }\end{array}$ & 1 \\
\hline $\begin{array}{l}\text { Sahiplik Teorisi } \\
\text { (Psychological Ownership) }\end{array}$ & 2 & $\begin{array}{l}\text { Anlam Oluşturma Teorisi } \\
\text { (Sense - Making Theory) }\end{array}$ & 1 \\
\hline $\begin{array}{l}\text { Sosyal Uygulama Teorisi } \\
\text { (Social Practice Theory) }\end{array}$ & 2 & $\begin{array}{l}\text { Genel Çevrimiçi Sosyal Etkileşim Eğilimi } \\
\text { (General Online Social İnteraction } \\
\text { Propensity) }\end{array}$ & 1 \\
\hline $\begin{array}{l}\text { Bilişsel Değerlendirme Teorisi (Cognitive } \\
\text { Appraisal Theory) }\end{array}$ & 2 & $\begin{array}{l}\text { Düzenleyici Odaklar Teorisi } \\
\text { (Regulatory Focus Theory) }\end{array}$ & 1 \\
\hline $\begin{array}{l}\text { Sosyal Ağlar Teorisi } \\
\text { (Social Networks Theory) }\end{array}$ & 2 & \begin{tabular}{|l|} 
Çizge Teorisi \\
(Graph Theory)
\end{tabular} & 1 \\
\hline $\begin{array}{l}\text { Hizmet Ekosistemi Teorisi } \\
\text { (Service Ecosystem Theory) }\end{array}$ & 2 & $\begin{array}{l}\text { Bilgi İşleme Teorisi } \\
\text { (Information Processing Theory) }\end{array}$ & 1 \\
\hline $\begin{array}{l}\text { Elverişlilik / Olanaklar Teorisi } \\
\text { (Theory of Affordances) }\end{array}$ & 2 & $\begin{array}{l}\text { Bilişsel Uyumsuzluk Teorisi } \\
\text { (Cognitive Dissonance Theory) }\end{array}$ & 1 \\
\hline $\begin{array}{l}\text { Sosyal Karşılık Teorisi } \\
\text { (Social Response Theory) }\end{array}$ & 2 & $\begin{array}{l}\text { Tüketici Sosyalleşme Teorisi (Consumer } \\
\text { Socialization Theory) }\end{array}$ & 1 \\
\hline $\begin{array}{l}\text { Düzenleyici Ilginlik Teorisi } \\
\text { (Regulatory Engagement Theory) }\end{array}$ & 2 & $\begin{array}{l}\text { Görev - Teknoloji Uyum Modeli (Task - } \\
\text { Technology Fit Model) }\end{array}$ & 1 \\
\hline $\begin{array}{l}\text { Karşııklı Bağımlılık Teorisi } \\
\text { (Interdependence Theory) }\end{array}$ & 2 & $\begin{array}{l}\text { Sistem Teorisi } \\
\text { (Systems Theory) }\end{array}$ & 1 \\
\hline $\begin{array}{l}\text { Atfetme (Nedensellik Yükleme) Teorisi } \\
\text { (Attribution Theory) }\end{array}$ & 2 & $\begin{array}{l}\text { Sebep Sonuç Zinciri Teorisi } \\
\text { (Means - End Theory View) }\end{array}$ & 1 \\
\hline $\begin{array}{l}\text { Bağlanma Teorisi } \\
\text { (Attachment Theory) }\end{array}$ & 2 & $\begin{array}{l}\text { Sosyal Psikoloji Teorileri } \\
\text { (Social Psychology Theories) }\end{array}$ & 1 \\
\hline $\begin{array}{l}\begin{array}{l}\text { Kaynak ve Yeterlilik Temelli Yaklaşım } \\
\text { (Resource and } \quad \text { Capabilities-Based } \\
\text { Perspective) }\end{array} \\
\end{array}$ & 2 & $\begin{array}{l}\text { Birlikte Değer Yaratma Teorisi } \\
\text { (Value Co-Creation Theory) }\end{array}$ & 1 \\
\hline $\begin{array}{l}\text { Hizmet Pazarlaması Teorisi } \\
\text { (Service Marketing Theory) }\end{array}$ & 2 & $\begin{array}{l}\text { Grup (Takım) Özdeşleşme Teorisi } \\
\text { (Team Identification Theory) }\end{array}$ & 1 \\
\hline
\end{tabular}

Pazarlama literatüründe, müşterilerin medya kullanımından sağladıkları faydaların neler olduğuna yönelik teorinin (Kullanımlar ve Doyumlar Teorisi, Katz, Blumler ve Gurevitch, 1973) ortaya atılmasından bu yana birçok araştırma yapılmış ve çeşitli faydaların keşfi gerçekleştirilmiştir. Bu çalışmaların müşteri ilginliği araştırmalarına da yön verdiği görülmektedir. Markalar, ürünler, hizmetlerden fayda elde etmek üzere hareket eden müşterilerin ilginlik davranışı gösterdiğine dair birçok çalışma yapılmıştır (örn. Ashley ve Tuten, 2015; Verhagen vd., 2015; Calder, Malthouse ve Maslowska, 2016).

illişkisel pazarlama teorisi (Morgan ve Hunt, 1994) de müşteri ilginliğini temellendirmek üzere kullanılmıştır (Brodie vd., 2011; Brodie vd., 2013; Hollebeek vd., 2014; Dessart, Veloutsou ve MorganThomas, 2015; Harwood ve Garry, 2015). Müşterileri ile sağlıklı iletişim kurabilen işletmeler müşteri ilginliğini de oluşturabilmektedirler (Brodie vd., 2013). Daha önemlisi müşteri ilginliği, yeni nesil müşteri ilişkilerinin yönetimi konusunda yeni bir dönemin varlığına işaret etmekte ve genellikle ilişkisel pazarlama bağlamında açıklanmaktadır (Malthouse vd., 2013). Bu bakımdan, bu çalışmada incelenen makaleler kapsamında da müşteri ilginliğinin ilişkisel pazarlama yaklaşımı ile temellendirilmeye çalışılması olağandır.

Insanların organizasyonlar ve diğer insanlarla olan ilişkilerini anlamak için kullanılan sosyal mübadele teorisine (Homans, 1958) göre, müşterilerin işletmeler ile ilişkilerini devam ettirmeleri için elde ettikleri toplam faydanın müşterinin maliyetlerinden daha yüksek olması gerekmektedir. Müşteriler ilişkiden kâr elde ettiklerini düşündükleri sürece işletme ile olan ilişkilerini devam ettireceklerdir. Bu ilişkisel yaklaşım, araştırmacılara ve yöneticilere etkili stratejiler üretme imkanı sunması bakımından, müşteri ilginliği 
araştırmalarına da dayanak olmuştur (So vd., 2014; O’Brien, Jarvis ve Soutar, 2015; Harrigan, Evers, Miles ve Daly, 2017).

Sosyal kimlik teorisi (Tajfel ve Turner, 1979), müşteri ilgilinliği kapsamında birçok çalışmada incelenmiştir (Aksoy vd., 2013; So vd., 2014; Zhang, Kandampully ve Bilgihan, 2015; Zheng, Kandampully ve Bilgihan, 2015). Özellikle çevrimiçi topluluklar bağlamındaki müşteri ilginliği çalışmalarında bu teoriden faydanıldığı görülmüştür. Üye oldukları çevrimiçi sosyal gruplara bağlılık geliştiren müşterilerin marka ve işletmelere de müşteri ilginliği geliştireceği varsayımları araştırılmış ve bu bağlamda olumlu kanıtlar bulunmuştur. Bireylerin bu ortamlarda sosyal bir kimlik kazandığı, kimlikleriyle grup kimlikleri arasında güçlü bir bağ oluşturdukları açığa çıkmıştır (So vd., 2014).

\subsection{Kullanılan Öncüller Bakımından Müşteri IIlginliği}

Müşteri ilginliği kavramının öncülleri, birçok ampirik çalışmada incelenmiştir. Çalışmada ele alınan 397 çalışmadan 140 adedinde, müşteri ilginliğinin bir ardıl olarak incelendiği görülmüştür. Buradan hareketle, ilginlik kavramının ardıl olarak ele alındığı çalışmalar incelenerek müşteri ilginliğinin öncüllerine ulaşılmıştır. Yapılan inceleme sonucunda, 105 adet kavramın müşteri ilginliğinin öncülü olarak ele alındığı sonucuna varılmıştır. İkiden fazla makalede incelenen kavramlar Şekil 3'te gösterilmiştir.

Şekil 3. Müşteri İlginliğinin Öncülleri

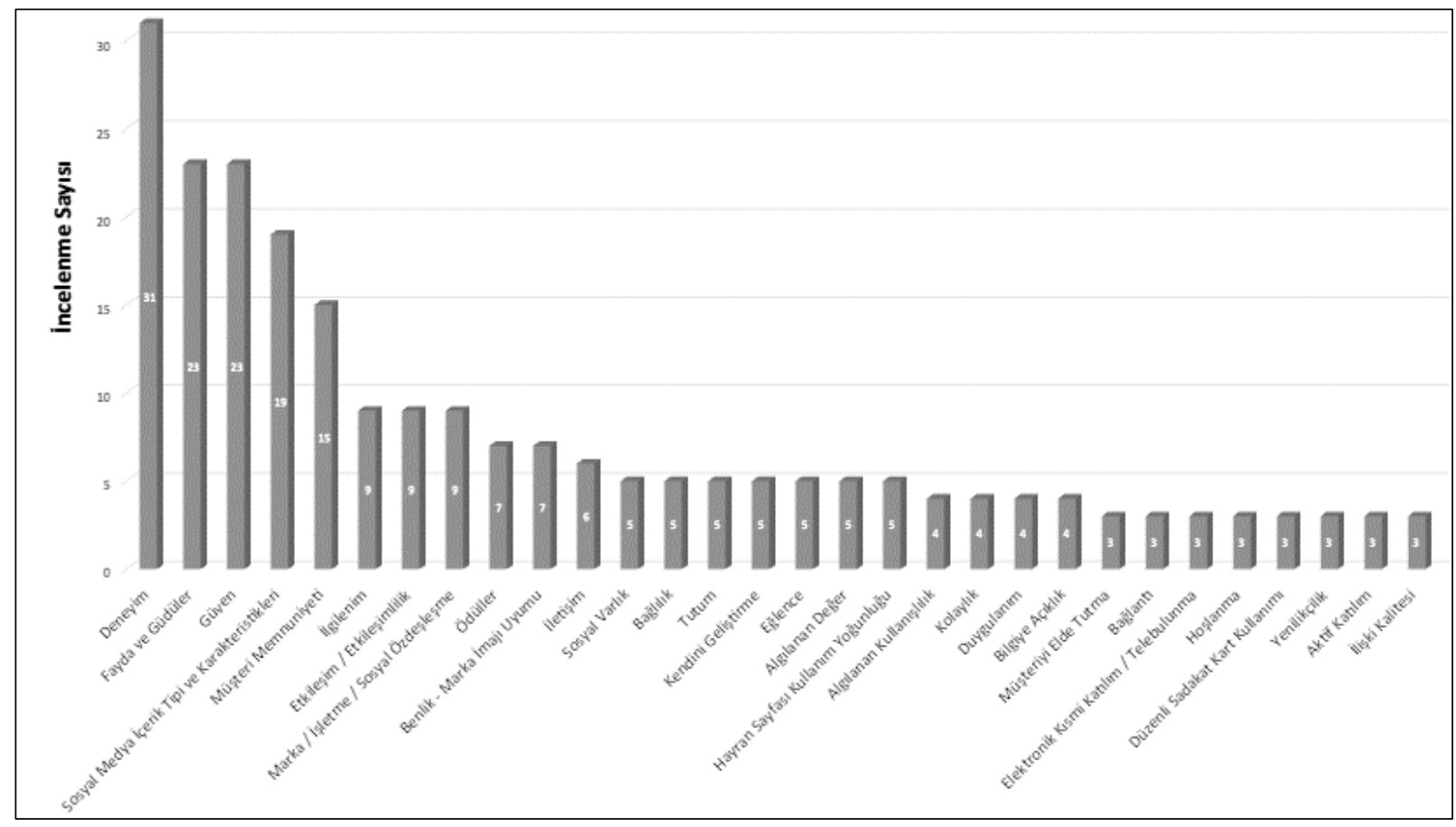

Tespit edilen öncüller incelendiğinde, "deneyim"in 31 adet makale ile en sık rastlanan müşteri ilginliği öncülü olduğu görülmektedir. Bu kavramı sırasıyla; "fayda ve güdüler" (23 çalışmada), "güven" (23 çalışmada), "sosyal medya içerik tip ve karakteristikleri" (19 çalışmada), "müşteri memnuniyeti" (15 çalışmada), "ilgilenim" (9 çalışmada), "etkileşim / etkileşimlilik" (9 çalışmada), "marka / işletme / sosyal özdeşleşme" (9 çalışmada) kavramları takip etmektedir.

\subsection{Ardılları Bakımından Müşteri İlginliği}

Bu çalışma kapsamında incelenen 397 çalışmadan 55'inde, müşteri ilginliği kavramının öncül olarak incelendiği görülmüştür. Ilginlik kavramının öncül olarak ele alındığı bu çalışmalar incelenerek müşteri ilginliğinin ardıllarına ulaşılmıştır. İncemeler sonucunda, 57 adet kavramın müşteri ilginliğinin ardılı olarak ele alındığı görülmüştür. Birden çok makalede incelenen kavramlar Şekil 4'te gösterilmiştir. 
Şekil 4. Müşteri Illginliğinin Ardılları

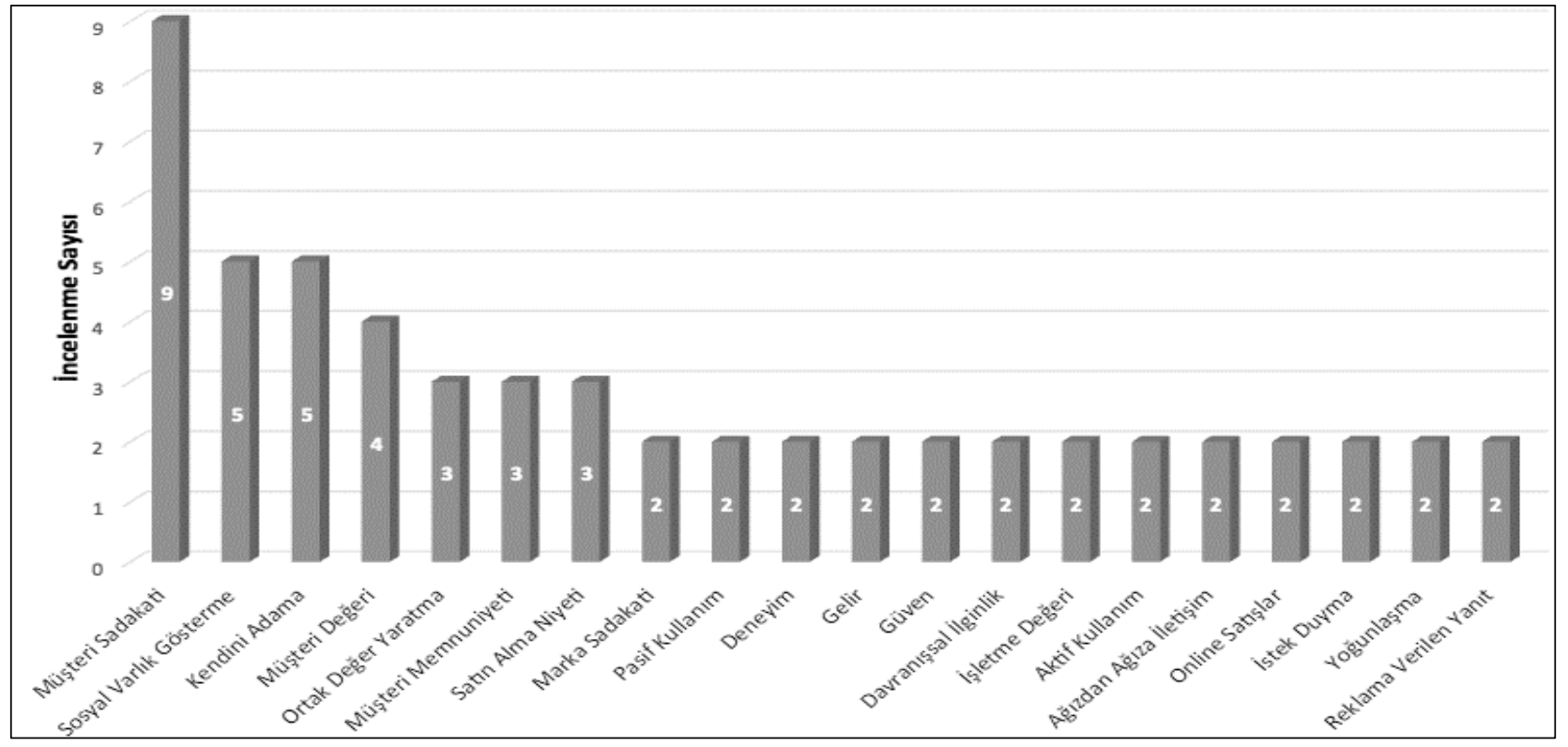

Tespit edilen ardıllar incelendiğinde, "müşteri sadakati”nin 9 adet makale ile en sık rastlanan müşteri ilginliği ardılı olduğu görülmektedir. Bu kavramı sırasıyla "sosyal varlık gösterme" (5 çalışmada), "kendini adama" (5 çalışmada), "müşteri değeri" (4 çalışmada), "ortak değer yaratma" (3 çalışmada), "müşteri memnuniyeti" (3 çalışmada) ve "satın alma niyeti" (3 çalışmada) kavramları takip etmektedir.

\section{Tartışma}

Müşterilerle kurulacak ilişkilerin yeni bir boyut kazanması ve müşteri ilişkileri yönetiminde yeni bakış açılarının oluşmasıyla birlikte (Malthouse vd., 2013), müşteri ilginliği pazarlamanın odağının yıllar içerisindeki gelişiminde nihai bir nokta olarak karşımıza çıkmaktadır (Pansari ve Kumar, 2017). Müşterinin, müşteri ilişkileri yönetiminde aktif bir katıımcı haline gelmesi, tüketici davranışlarında yeni bir dönemi beraberinde getirmiş ve böylelikle, müşteri ilginliği kavramı akademinin ve iş dünyasının artan ilgisine neden olmuştur. Bu çalışmada da, giderek artan ilgiden hareketle, müşteri ilginliği kavramının çok yönlü yapısının daha iyi anlaşılması ihtiyacını gidermek üzere bir literatür taraması gerçekleştirilerek kavrama yönelik çalışmaların bir özeti sunulmuştur.

Çalışma kapsamında yapılan ön incelemeyle, literatürdeki araştırma çağrılarıyla paralel olarak (Islam ve Rahman, 2016; Kumar ve Pansari, 2016), müşteri ilginliğine yıllar içerisinde artan bir ilginin olduğu görülmüştür. Türkçe literatürdeki çalışma azlığı ise dikkat çekmektedir. Bu bakımdan, kavramın Türkçeleştirilmesi noktasında da farklı görüşler bulunmaktadır. Buradan hareketle bu çalışmada; müşteri ilginliği üzerine derinlemesine bir analiz yapma, kavramın Türkçeleştirilmesi ve Türkçe literatürün bu bağlamda geliştirilmesine katkı sağlama, gelecek araştırmalar ve iş dünyası için müşteri ilginliği üzerine çıkarımlarda bulunma amaçlarıyla, 397 makalenin incelenmesi neticesinde çeşitli bulgular elde edilmiştir.

Müşteri ilginliği literatürü incelendiğinde; kavramın tanımı, boyutları ve katılımcıları (içerdiği taraflar) hakkında farklı görüşler olduğu görülmektedir. Çalışma kapsamında incelenen makaleler de bu duruma paralel olarak, içerdikleri farklı yaklaşımlar bakımından tasnif edilmiştir. Çalışma kapsamında, literatürde kabul gören bazı tanımlar incelenmiştir. Müşteri ilginliği tanımlarının, psikolojik ve davranışsal olarak iki kategoriye ayrılabildiği görülmüştür. Ek olarak, kavramın genel olarak bilişsel, duygusal ve davranışsal boyutlardan oluştuğuna yönelik genel anlayışı takiben, incelenen çalışmaların da çoğunlukta bu üç boyutu kapsar şekilde olduğu görülmüştür (örn. Brodie vd., 2011; Hollebeek, 2011; Nguyen vd., 2016; Harmeling vd., 2017). 
İncelenen makalelerde öne çıkan bazı yaklaşımların ve teorik dayanakların olduğu görülmüştür. Bu bakımdan, en yaygın şekilde benimsenen yaklaşımın Illginlik Uygulama Alanları olduğu görülmüştür. Takip eden kategorinin ise Strateji olduğu gözlemlenmiştir. Kavramın farklı bağlamlarda incelenerek, bu bağlamlardaki işleyişi ve beraberinde getireceği stratejik avantajlar akademinin ilgisini çekmiştir. Teorik olarak en sık rastlanan temel dayanaklardan bazıları ise, Hizmet Egemen Mantık (Vargo ve Lusch, 2004), Kullanımlar ve Doyumlar Teorisi (Katz vd., 1973) ve Ilişkisel Pazarlama Teorisi'dir (Morgan ve Hunt, 1994). Buradan hareketle, konuya hizmet pazarlaması bağlamındaki yoğun ilgi dikkat çekmektedir. Bireylerin beklentilerini anlayabilmek adına, kullanımlar ve doyumların incelendiği de görülmektedir. Kavramın çıkış noktasına da işaret eden, müşteri ilişkileri yönetimindeki yeni döneme dikkat çeken ilişkisel pazarlama teorisi de olağan bir biçimde karşımıza çıkmaktadır. Ek olarak, literatürde nicel bulgular elde etmek üzere yoğun bir çaba olduğu da gözlemlenmiştir. Bu bakımdan, nitel çalışmaların veya karma yöntemlerin daha az kullanıldığı görülmüştür.

Müşteri ilginliği, öncülleri ve ardılları bakımından incelendiğinde öncül ve ardılların, Van Doorn vd. (2010)'nin kavramsal çalışmalarında bahsettikleri kategoriler dikkate alındığında (müşteri odaklı, firma odaklı, bağlam odaklı), daha çok müşteri odaklı olduğu görülmektedir. İlginlik kavramının öznesi genellikle "müşteri" olduğu için, müşteri odaklı değişkenlere (deneyim, fayda ve güdüler, güven, sadakat vb.) daha sık rastlanması olağandır (Dovalienè vd., 2016; Fang vd., 2017). Firma odaklı (örn. online satışlar, müşteriyi elde tutma) veya durum odaklı (hayran sayfası kullanım yoğunluğu, telebulunma) bazı öncül ve ardıllar da gözlemlenmiştir. Öte yandan, bazı değişkenler hem ardıl hem de öncül olarak kullanılmıştır (örn. deneyim, güven). Bu durum, müşteri ilginliğinin çok yönlü ve çok katılımcılı olmasıyla açıklanabileceği gibi, gelecek çalışmalara yönelik bir inceleme alanını da beraberinde getirmektedir. Gelecek çalışmalarda, müşteri ilginliğinin ve ilgili boyutların birbirinin oluşumundaki etkileri yeniden gözden geçirilerek bilhassa hangi bağlamda öncül hangi bağlamda ardıl olacakları açığa çıkarılabilir.

Tüm bu bulgulardan hareketle bu çalışmada, araştırmanın temel amaçlarından birini gerçekleştirerek müşteri ilginliğinin kavramsallaşmasına katkıda bulunmak üzere bir müşteri ilginliği tanımlaması yapılmıştır. Çalışma kapsamında incelenen müşteri ilgilinliği literatür özeti kapsamında elde edilen müşteri ilginliği tanımları, boyutları, teorik kapsamı, öncülleri ve ardılları incelenmiş ve bunların tümünü kapsayan, müşteri ilginliğinin çok yönlü yapısını temsil eden, konu üzerine çalışacaklar için kavramın özelliklerini ve doğasını bir bakışta aktarmaya odaklanan müşteri ilginliği tanımı ve açıklaması şu şekilde yapılmıştır:

Müşteri ilginliği, bireylerin işletme/marka ile etkileşiminde ve iletişiminde yer alan taraflarla olan deneyimleri neticesinde gerçekleşen; duygusal, bilişsel ve davranışsal gibi boyutları kapsayan çok boyutlu bir yapıdır. Müşteri ilginliği; işletme, müşteri ve durum-bazlı yapılar sayesinde ortaya çıkan ve çeşitli davranışsal göstergeler vasıtasıyla gözlemlenebilen (olumlu ağızdan ağıza iletişim, diğer müşterilere yardım etme, öneride bulunma vb.) psikolojik bir durumdur. Ayrıca, kavramın farklı tarafları içerecek şekilde farklı bağlamlara uyarlanması mümkündür.

\section{Yönetimsel ve Teorik Çıkarımlar}

Çalışmada yapılan incelemeler neticesinde hem akademi hem iş dünyasına yönelik bir yol haritası sunulmaktadır. İş dünyasında, bu çalışmada sunulan bulguların çeşitli şekillerde kullanılabilmesi mümkündür. Örneğin öncüllere yönelik bulgular, firmaların müşteri ilginliği oluşturabilmek için odaklanması gereken noktaları göstermektedir. Şekil 3'teki bulgular incelendiğinde, müşteri ilginliğinin oluşumunda etkili bir boyut olarak karşımıza çıkan deneyim, işletmelerin bu hususta odaklanması gereken temel konulardandır. Müşteri ilginliği oluşturmak isteyen bir işletme, faaliyet gösterdiği pazar ve müşterilerinin özelliklerini göz önünde bulundurarak müşteri deneyimi oluşturmalıdır. Müşteri ilginliği oluşmasıyla elde edilebilecek çıktılar ise, bu çalışmada öne çıkan ardıllar vasıtasıyla tahmin edilebilir. Örneğin, müşteri sadakati oluşturmak isteyen bir işletme, müşteri ilginliği davranışının önemini göz ardı etmemelidir. Benzer şekilde, incelenen çalışmaların yaklaşımları ve ele aldıkları konular da iş dünyasına bir durum analizi sunacaktır. Bilhassa, Strateji ve ilginlik Uygulama Alanları kategorilerindeki çalışmalar, müşteri ilginliğinin özellikle hangi alanlar için önemli olduğunu ve bu alanlarda ne gibi sonuçlar ortaya çıkardığını göstermektedir. Örneğin, Tablo 3 müşteri ilginliğinin sosyal medya pazarlaması bağlamında önemli bir konu olduğunu göstermektedir. Bu bakımdan, 
sosyal medya pazarlamasını pazarlama süreçlerinin bir alanı olarak gören işletmelerin müşteri ilginliği davranışının açığa çıkmasını sağlamaya çalışmaları doğru bir strateji olarak görülebilir.

Çalışma bulguları aynı zamanda, müşteri ilginliği literatürünün bir fotoğrafını sunması bakımından teorinin gelişmesine katkı sağlamakta ve gelecek araştırmalara yön vermektedir. Derleme çalışmalarının temel katkılarından biri olarak görülebilecek, araştırmacının ele aldığı konunun farklı yönlerden detaylandırılmış bir özetinin sunulması, bu çalışmada müşteri ilginliğinin öneminin vurgulanması bağlamında gerçekleştirilmiştir. Illk olarak, ilginlik kavramına yaklaşımlar ve incelenen konular, literatürün detaylandırılmış bir ana özetini göstermekte ve bilhassa keşfedilmemiş bağlamları bir bakışta görebilme noktasında araştırmacılara katkı sağlamaktadır. Gelecek araştırmalarda, mevcut ilginlik araştırmalarının değindiği hususlar, bu hususları ele alış biçimleri veya henüz hiç keşfedilmemiş noktaları anlamak üzere, bu çalışmada sunulan bulgulardan faydalanılabilir. Örneğin, müşteriği ilginliği konusunda çalışma yapmak isteyen bir araştırmacı, bu çalışmadan faydalanarak müşteri ilginliğinin çok boyutlu yapısını ve bağlama göre farklı yaklaşımlarla ele alınmasının mümkün olduğunu hızlı bir biçimde görebilir. Bu çalışmadaki boyutların açıklanış yaklaşımından hareketle, bir araştırmacı, müşteri ilginliğini tek boyutlu mu yoksa çok boyutlu bir şekilde mi ele alması gerektiğine veya kendi bağlamında bilhassa hangi boyut/boyutlar çerçevesinde ele alacağına daha kolay bir biçimde karar verebilir. Öte yandan, bu çalışmada müşteri ilginliğine yönelik sunulan teoriler, gelecek araştırmaların teorik olarak kurgulanmasına ve araştırma sorularına temel bir dayanak oluşturmasına yardımcı olacaktır. Bu bağlamda araştırmacılar, bu çalışmadan faydalanarak ilgili teorik dayanağın farklı şekillerde nasıl ele alınabileceğini veya henüz hiç uyarlanmamış ancak alan için önemli olabilecek farklı teorik yaklaşımları daha kolay bir biçimde keşfedebilirler. Aynı zamanda, ilginlik kavramını açıklama veya açıklanmak istenen bir kavramı ilginlik vasıtasıyla inceleme motivasyonlarıyla hareket edecek araştırmacılar, bu çalışmada sunulan öncül ve ardıllardan faydalanabilecektir. Örneğin, bu çalışma müşteri ilginliğinin ardıllarına odaklanma noktasında literatürde nispeten az bir ilginin olduğunu göstermektedir. Halbuki müşteri ilginliğinin ardıllarını anlamak, kavramın önemini anlamanın etkili bir yoludur. Müşteri ilginliği literatürüne katkı sunmak isteyen bir araştırmacı, bilhassa ilginliğin çıktılarını anlamaya odaklanabilir ve bunu yaparken hangi ilişkilerin literatürde baskın bir şekilde var olduğunu, hangi ilişkilerin ise henüz hiç ele alınmamış olduğunu hızlıca görebilir. Bu bakımdan bu çalışma, araştırmacıların gelecekteki araştırmalarında ele alacakları ilişkileri desteklemelerine yardımcı olacak bir araç sunmaktadır. Benzer şekilde, bu çalışmanın bulguları, araştırmacıların henüz keşfedilmemiş ilişkilere yönelebilmeleri için de kapsamlı bir kaynak olarak kullanılabilecektir. Örneğin, birer araştırma boşluğu olarak duygular veya marka kavramına özgü değişkenler bağlamındaki ilişkilere odaklanmak katkı sağlayıcı olabilir. Son olarak, bu çalışmada yürütülen tüm incelemelerin bir çıktısı olarak sunulan müşteri ilginliği tanım ve açıklamasının, literatürdeki tanımlamaya bir katkı sağlayacağına inanılmaktadır. Çünkü bu çalışmayla, hem kavramın Türkçeleştirilmesi ve müşteri ilginliği konusundaki Türkçe literatürün geliştirilmesi noktasında bir adım atılmış hem de müşteri ilginliği literatürünün çok yönlü ve karmaşık yapısının kolay anlaşılır bir şekilde sunulması için bir çaba sergilenmiştir.

\section{Sonuç}

Müşteri ilginliği kavramını derinlemesine analiz edebilmek ve kavramın Türkçeleştirilmesi ve bu bağlamdaki Türkçe literatürün gelişmesine katkı sağlamak amacıyla bu çalışmada, kavramın dünü ve bugününe yönelik bir inceleme gerçekleştirilmiştir. Çalışma kapsamında, WOS veri tabanı vasıtasıyla bir literatür incelemesi yapılmış ve elde edilen çalışmalar çeşitli odak noktaları bakımından analiz edilmiştir. Literatür incelemesi sonucunda elde edilen bulgular kavramın dünü ve bugününü anlamak için yol gösterici olmuş, iş dünyası için bir mevcut durum analizi ve gelecek çalışmalar için ise bir araştırma ajandası sunarak literatüre katkı sağlamıştır. 


\section{Beyan ve Açıklamalar (Disclosure Statements)}

1. Bu çalışmanın yazarları, araştırma ve yayın etiği ilkelerine uyduklarını kabul etmektedirler (The authors of this article confirm that their work complies with the principles of research and publication ethics).

2. Yazarlar tarafından herhangi bir çıkar çatışması beyan edilmemiştir (No potential conflict of interest was reported by the authors).

3. Bu çalışma, intihal tarama programı kullanılarak intihal taramasından geçirilmiștir (This article was screened for potential plagiarism using a plagiarism screening program).

\section{Son Notlar}

1. Bu çalışma, Coşkun Ermehan'ın Yüksek Lisans tezinden üretilmiştir.

\section{Kaynaklar}

Aksoy, L., van Riel, A., Kandampully, J., Wirtz, J., Den Ambtman, A., Bloemer, J., ... Gurhan Canli, Z. (2013). Managing brands and customer engagement in online brand communities. Journal of Service Management, 24(3), 223-244.

AlSkaif, T., Lampropoulos, I., van den Broek, M., \& van Sark, W. (2018). Gamification-based framework for engagement of residential customers in energy applications. Energy Research \& Social Science, 44, 187-195.

Appelbaum, A. (2001). The constant customer. Gallup Business Journal, 745, https://news.gallup.com/businessjournal/745/constant-customer.aspx (Erişim Tarihi: 10 Nisan 2019).

Arya, V., Sethi, D., \& Verma, H. (2018). Are emojis fascinating brand value more than textual language? Mediating role of brand communication to SNS and brand attachment: An insight from India. Corporate Communications, 23(4), 648-670.

Ashley, C., \& Tuten, T. (2015). Creative strategies in social media marketing: An exploratory study of branded social content and consumer engagement. Psychology \& Marketing, 32(1), 15-27.

Bianchi, C., \& Andrews, L. (2018). Consumer engagement with retail firms through social media: An empirical study in Chile. International Journal of Retail and Distribution Management, 46(4), 364-385.

Bitter, S., \& Grabner-Kräuter, S. (2016). Consequences of customer engagement behavior: When negative Facebook posts have positive effects. Electronic Markets, 26(3), 219-231.

Boardman, D., Raciti, M. M., \& Lawley, M. (2016). Exploring the influence of envy on service engagement. The Service Industries Journal, 36(7-8), 278-298.

Bowden, J. L., Gabbott, M., \& Naumann, K. (2015). Service relationships and the customer disengagement-engagement conundrum. Journal of Marketing Management, 31(7-8), 774-806.

Bowden, J. L. H., Conduit, J., Hollebeek, L. D., Luoma-aho, V., \& Solem, B. A. (2017). Engagement valence duality and spillover effects in online brand communities. Journal of Service Theory and Practice, 27(4), 877-897.

Braun, C., Batt, V., Bruhn, M., \& Hadwich, K. (2016). Differentiating customer engaging behavior by targeted benefits An empirical study. Journal of Consumer Marketing, 33(7), 528-538.

Brodie, R. J., Hollebeek, L. D., Jurić, B., \& Ilić, A. (2011). Customer engagement: Conceptual domain, fundamental propositions, and implications for research. Journal of Service Research, 14(3), 252-271.

Brodie, R. J., Ilic, A., Juric, B., \& Hollebeek, L. (2013). Consumer engagement in a virtual brand community: An exploratory analysis. Journal of Business Research, 66(1), 105-114.

Busalim, A. H. (2016). Understanding social commerce: A systematic literature review and directions for further research. International Journal of Information Management, 36(6), 1075-1088.

Busalim, A. H., Hussin, A. R. C., \& lahad, N. A. (2019). Factors influencing customer engagement in social commerce websites: A systematic literature review. Journal of Theoretical and Applied Electronic Commerce Research, 14(2), 1-14.

Calder, B. J., Malthouse, E. C., \& Maslowska, E. (2016). Brand marketing, big data and social innovation as future research directions for engagement. Journal of Marketing Management, 32(5-6), 579-585.

Cambra, J., Melero, I., \& Sese, F. (2012). Customer engagement: An exploratory study in the mobile communications industry. Universia Business Review, 33, 84-103. 
Carlson, J., Rahman, M., Voola, R., \& De Vries, N. (2018). Customer engagement behaviours in social media: Capturing innovation opportunities. Journal of Services Marketing, 32(1), 83-94.

Chahal, H., \& Rani, A. (2017). How trust moderates social media engagement and brand equity. Journal of Research in Interactive Marketing, 11(3), 312-335.

Chandler, J. D., \& Lusch, R. F. (2015). Service Systems: A Broadened Framework and Research Agenda on Value Propositions, Engagement, and Service Experience. Journal of Service Research, 18(1), 6-22.

Chathoth, P. K., Ungson, G. R., Altinay, L., Chan, E. S., Harrington, R., \& Okumus, F. (2014). Barriers affecting organisational adoption of higher order customer engagement in tourism service interactions. Tourism Management, 42, 181-193.

Chathoth, P. K., Ungson, G. R., Harrington, R. J., \& Chan, E. S. W. (2016). Co-creation and higher order customer engagement in hospitality and tourism services: A critical review. International Journal of Contemporary Hospitality Management, 28(2), 222-245.

Chen, X., Yu, H., Gentry, J. W., \& Yu, F. (2017). Complaint or recommendation? The impact of customers' state and trait goal orientations on customer engagement behaviors. Journal of Consumer Behaviour, 16(2), 187-194.

Chuang, H. M., \& Chen, Y. S. (2015). Identifying the value co-creation behavior of virtual customer environments using a hybrid expert-based DANP model in the bicycle industry. Human-Centric Computing and Information Sciences, 5(1), 1-31.

Clark, M., Black, H. G., \& Judson, K. (2017). Brand community integration and satisfaction with social media sites: A comparative study. Journal of Research in Interactive Marketing, 11(1), 39-55.

Dellarocas, C., \& Narayan, R. (2006). A statistical measure of a population's propensity to engage in post-purchase online word-of-mouth. Statistical Science, 21(2), 277-285.

Dessart, L., Veloutsou, C., \& Morgan-Thomas, A. (2015). Consumer engagement in online brand communities: A social media perspective. Journal of Product \& Brand Management, 24(1), 28-42.

Dessart, L., Veloutsou, C., \& Morgan-Thomas, A. (2016). Capturing consumer engagement: Duality, dimensionality and measurement. Journal of Marketing Management, 32(5-6), 399-426.

Dijkmans, C., Kerkhof, P., \& Beukeboom, C. J. (2015). A stage to engage: Social media use and corporate reputation. Tourism Management, 47, 58-67.

Dovalienè, A., Piligrimienè, Ž., \& Masiulytè, A. (2016). Factors influencing customer engagement in mobile applications. Engineering Economics, 27(2), 205-212.

Elise, C., Donthu, N., Macelroy, W. H., \& Wydra, D. (2010). How to foster and sustain engagement in virtual communities constance. University of California Press, 13(3), 293-293.

Fang, J., Zhao, Z., Wen, C., \& Wang, R. (2017). International Journal of Information Management Design and performance attributes driving mobile travel application engagement. International Journal of Information Management, 37(4), 269-283.

Fang, Y. H. (2017). Beyond the usefulness of branded applications: Insights from consumer-brand engagement and selfconstrual perspectives. Psychology \& Marketing, 34(1), 40-58.

Gambetti, R. C., Graffigna, G., \& Biraghi, S. (2012). The Grounded theory approach to consumer-brand engagement: The practitioner's standpoint. International Journal of Market Research, 54(5), 659-687.

Gebauer, H., Johnson, M., \& Enquist, B. (2010). Value co-creation as a determinant of success in public transport services: A study of the Swiss Federal Railway operator (SBB). Managing Service Quality, 20(6), 511-530.

Geissinger, A., \& Laurell, C. (2016). User engagement in social media: An explorative study of Swedish fashion brands. Journal of Fashion Marketing and Management, 20(2), 177-190.

Graffigna, G. (2017). Is a transdisciplinary theory of engagement in organized settings possible? A concept analysis of the literature on employee engagement, consumer engagement and patient engagement. Frontiers in Psychology, 8, 1-17.

Graffigna, G., \& Gambetti, R. C. (2015). Grounding consumer-brand engagement: A field-driven conceptualisation. International Journal of Market Research, 57(4), 605.

Groeger, L., Moroko, L. \& Hollebeek, L. D. (2016). Capturing value from non-paying consumers' engagement behaviours: Field evidence and development of a theoretical model. Journal of Strategic Marketing, 24(3-4), $190-209$.

Guo, L., Zhang, M., \& Wang, Y. (2016). Effects of customers' psychological characteristics on their engagement behavior in company social networks. Social Behavior and Personality: An International Journal, 44(10), 1661-1670. 
Gupta, S., Pansari, A., \& Kumar, V. (2018). Global customer engagement. Journal of International Marketing, 26(1), 429.

Gutiérrez-Cillán, J., Camarero-Izquierdo, C., \& San José-Cabezudo, R. (2017). How brand post content contributes to user's Facebook brand-page engagement. The experiential route of active participation. Business Research Quarterly, 20(4), 258-274.

Gvili, Y., \& Levy, S. (2018). Consumer engagement with eWOM on social media: The role of social capital. Online Information Review, 42(4), 482-505.

Hapsari, R., Clemes, M. D., \& Dean, D. (2017). The impact of service quality, customer engagement and selected marketing constructs on airline passenger loyalty. International Journal of Quality and Service Sciences, 9(1), 2140.

Harmeling, C. M., Moffett, J. W., Arnold, M. J., \& Carlson, B. D. (2017). Toward a theory of customer engagement marketing. Journal of the Academy of Marketing Science, 45(3), 312-335.

Harrigan, P., Evers, U., Miles, M. P., \& Daly, T. (2018). Customer engagement and the relationship between involvement, engagement, self-brand connection and brand usage intent. Journal of Business Research, 88, 388-396.

Harwood, T., \& Garry, T. (2015). An investigation into gamification as a customer engagement experience environment. Journal of Services Marketing, 29(6-7), 533-546.

Heims, E. \& Lodge, M. (2018). Customer engagement in UK water regulation: Towards a collaborative regulatory state? Policy \& Politics, 46(1), 81-100.

Hendry, S. (2016). The customer forum-putting customers at the centre of regulating water services. Water Policy, 18(4), 948-963.

Hollebeek, L. (2011). Exploring customer brand engagement: definition and themes. Journal of Strategic Marketing, 19(7), 555-573.

Hollebeek, L. D., Glynn, M. S., \& Brodie, R. J. (2014). Consumer brand engagement in social media: Conceptualization, scale development and validation. Journal of Interactive Marketing, 28(2), 149-165.

Hollebeek, L. D., Srivastava, R. K., \& Chen, T. (2016). SD logic-informed customer engagement: Integrative framework, revised fundamental propositions, and application to CRM. Journal of the Academy of Marketing Science, 47(1), 161-185.

Homans, G. C. (1958). Social behavior as exchange. American Journal of Sociology, 63(6), 597-606.

Ibrahim, N. F., Wang, X., \& Bourne, H. (2017). Exploring the effect of user engagement in online brand communities: Evidence from Twitter. Computers in Human Behavior, 72, 321-338.

Islam, J., \& Rahman, Z. (2017). The impact of online brand community characteristics on customer engagement: An application of Stimulus-Organism-Response paradigm. Telematics and Informatics, 34(4), 96-109.

Islam, J. U., \& Rahman, Z. (2016). The transpiring journey of customer engagement research in marketing: A systematic review of the past decade. Management Decision, 54(8), 2008-2034.

Islam, J. U., Rahman, Z., \& Hollebeek, L. D. (2018). Consumer engagement in online brand communities: A solicitation of congruity theory. Internet Research, 28(1), 23-45.

Jaakkola, E., \& Alexander, M. (2014). The role of customer engagement behavior in value co-creation: A service system perspective. Journal of Service Research, 17(3), 247-261.

Jani, N. M., Hafiz, M., Maksom, Z., Shariff, M., \& Mustapha, R. (2018). Consequences of customer engagement in social networking sites: Employing fuzzy delphi technique for validation. International Journal of Advanced Computer Science and Applications, 9(9), 283-293.

Lee, D., Hosanagar, K., \& Nair, H. S. (2018). Advertising content and consumer engagement on social media: Evidence from Facebook. Management Science, 64(11), 5105-5131.

Li, C., Cui, G., \& Peng, L. (2017). The signaling effect of management response in engaging customers: A study of the hotel industry. Tourism Management, 62, 42-53.

Littlechild, S. (2016). Contrasting developments in UK energy regulation: Retail policy and consumer engagement. Economic Affairs, 36(2), 118-132.

Johnson, A. G., \& Neuhofer, B. (2017). Airbnb - an exploration of value co-creation experiences in Jamaica. International Journal of Contemporary Hospitality Management, 29(9), 2361-2376.

Jonas, J. M., Boha, J., Sörhammar, D., \& Moeslein, K. M. (2018). Stakeholder engagement in intra- and interorganizational innovation. Journal of Service Management, 29(3), 399-421. 
Katz, E., Blumler, J. G., \& Gurevitch, M. (1973). Uses and gratifications research. The public Opinion Quarterly, 37(4), 509-523.

Khobzi, H., \& Teimourpour, B. (2015). LCP segmentation: A framework for evaluation of user engagement in online social networks. Computers in Human Behavior, 50, 101-107.

King, C. (2017). Brand management - standing out from the crowd: A review and research agenda for hospitality management. International Journal of Contemporary Hospitality Management. 29(1), 115-140.

Koufaris, M., Kambil, A., \& LaBarbera, P. A. (2001). Consumer behavior in web-based commerce: An empirical study. International Journal of Electronic Commerce, 6(2), 115-138.

Kumar, V. (2017). A theory of customer valuation: Concepts, metrics, strategy, and Implementation. Journal of Marketing, 82(1), 1-19.

Kumar, V., Aksoy, L., Donkers, B., Venkatesan, R., Wiesel, T., \& Tillmanns, S. (2010). Undervalued or overvalued customers: Capturing total customer engagement value. Journal of Service Research, 13(3), 297-310.

Kumar, V., \& Pansari, A. (2016). Competitive Advantage through engagement. Journal of Marketing Research, 53(4), 497-514.

Lei, S. S. I., Pratt, S., \& Wang, D. (2017). Factors influencing customer engagement with branded content in the social network sites of integrated resorts. Asia Pacific Journal of Tourism Research, 22(3), 316-328.

Li, L. P., Juric, B., \& Brodie, R. J. (2017). Dynamic multi-actor engagement in networks: the case of United Breaks Guitars. Journal of Service Theory and Practice, 27(4), 738-760.

Lin, S., Yang, S., Ma, M., \& Huang, J. (2018). Value co-creation on social media: Examining the relationship between brand engagement and display advertising effectiveness for Chinese hotels. International Journal of Contemporary Hospitality Management, 30(4), 2153-2174.

Liu, L., Lee, M. K. O., Liu, R., \& Chen, J. (2018). Trust transfer in social media brand communities: The role of consumer engagement. International Journal of Information Management, 41(28), 1-13.

Malthouse, E. C., Haenlein, M., Skiera, B., Wege, E., \& Zhang, M. (2013). Managing customer relationships in the social media era: Introducing the social CRM house. Journal of Interactive Marketing, 27(4), 270-280.

Marbach, J., Lages, C. R., \& Nunan, D. (2016). Who are you and what do you value? Investigating the role of personality traits and customer-perceived value in online customer engagement. Journal of Marketing Management, 32(56), 502-525.

Marino, V., \& Lo Presti, L. (2018). Engagement, satisfaction and customer behavior-based CRM performance: An empirical study of mobile instant messaging. Journal of Service Theory and Practice, 28(5), 682-707.

Maslowska, E., Malthouse, E. C., \& Collinger, T. (2016). The customer engagement ecosystem. Journal of Marketing Management, 32(5-6), 469-501.

Moliner, M. Á., Monferrer-tirado, D., Estrada-guillén, M., Moliner, M. Á., Monferrer-tirado, D., \& Estrada-guillén, M. (2018). Consequences of customer engagement and customer self-brand connection. Journal of Services Marketing, 32(4), 387-399.

Muñoz-Expósito, M., Oviedo-García, M. Á., \& Castellanos-Verdugo, M. (2017). How to measure engagement in Twitter: advancing a metric. Internet Research, 27(5), 1122-1148.

Morgan, R. M., \& Hunt, S. D. (1994). The commitment-trust theory of relationship marketing. Journal of Marketing, 58(3), 20-38.

Nguyen, L. T. V., Conduit, J., Lu, V. N., \& Rao Hill, S. (2016). Engagement in online communities: Implications for consumer price perceptions. Journal of Strategic Marketing, 24(3-4), 241-260.

O'Brien, I. M., Jarvis, W., \& Soutar, G. N. (2015). Integrating social issues and customer engagement to drive loyalty in a service organisation. Journal of Services Marketing, 29(6-7), 547-559.

Orenga-Roglá, S., \& Chalmeta, R. (2016). Social customer relationship management: taking advantage of Web 2.0 and Big Data technologies. SpringerPlus, 5(1), 1462.

Osei-Frimpong, K., \& McLean, G. (2018). Examining online social brand engagement: A social presence theory perspective. Technological Forecasting and Social Change, 128, 10-21.

Pansari, A., \& Kumar, V. (2017). Customer engagement: the construct, antecedents, and consequences. Journal of the Academy of Marketing Science, 45(3), 294-311.

Paruthi, M., \& Kaur, H. (2017). Scale development and validation for measuring online engagement. Journal of Internet Commerce, 16(2), 127-147. 
Pawsey, N., Nayeem, T., \& Huang, X. (2018). Use of Facebook to engage water customers: a comprehensive study of current UK and Australian practices and trends. Journal of Environmental Management, 228, 517-528.

Pittaway, S. (2016). Engaging students, shaping services: the changing face of student engagement at The Hive. Insights: The UKSG Journal, 29(3), 249-257.

Ponds, K. T., Arefi, A., Sayigh, A., \& Ledwich, G. (2018). Aggregator of demand response for renewable integration and customer engagement: Strengths, weaknesses, opportunities, and threats. Energies, 11(9), 1-20.

Pongpaew, W., Speece, M., \& Tiangsoongnern, L. (2017). Social presence and customer brand engagement on Facebook brand pages. Journal of Product and Brand Management, 26(3), 262-281.

Potra, S., Izvercian, M., \& Miclea, S. (2016). Changes in CRM approach: Refined functional blocks for customer creative engagement in services. International Journal of Information Systems in the Service Sector, 8(1), 45-57.

Ramaswamy, V., \& Ozcan, K. (2016). Brand value co-creation in a digitalized world: An integrative framework and research implications. International Journal of Research in Marketing, 33(1), 93-106.

Risitano, M., Romano, R., Sorrentino, A., \& Quintano, M. (2017). The impact of consumer-brand engagement on brand experience and behavioural intentions: An Italian empirical study. British Food Journal, 119(8), 1884-1896.

Robinson, N. M., \& Celuch, K. G. (2016). Strategic and bonding effects of enhancing the student feedback process. Journal of Marketing for Higher Education, 26(1), 20-40.

Romero, J. (2018). Exploring customer engagement in tourism: Construct proposal and antecedents. Journal of Vacation Marketing, 24(4), 293-306.

Roy, S. K., Balaji, M. S., Soutar, G., Lassar, W. M., \& Roy, R. (2018a). Customer engagement behavior in individualistic and collectivistic markets. Journal of Business Research, 86, 281-290.

Roy, S. K., Shekhar, V., Lassar, W. M., \& Chen, T. (2018b). Customer engagement behaviors: The role of service convenience, fairness and quality. Journal of Retailing and Consumer Services, 44, 293-304.

Röndell, J. G., Sörhammar, D., \& Gidhagen, M. (2016). Co-governance in the consumer engagement process: Facilitating multi-beneficial value creation. Journal of Strategic Marketing, 24(3-4), 327-345.

Sawhney, M., Verona, G., \& Prandelli, E. (2005). Collaborating to create: The Internet as a platform for customer engagement in product innovation. Journal of Interactive Marketing, 19(4), 4-17.

Shahrokh, Z. D., \& Poursaeed, M. M. (2015). Managing Non-Organic Virtual Brand Communities in Social Networking Sites. International Journal of E-Business Research, 11(4), 47-62.

Sharma, S., \& Conduit, J. (2016). Cocreation culture in health care organizations. Journal of Service Research, 19(4), 438457.

Simon, F., \& Tossan, V. (2018). Does brand-consumer social sharing matter? A relational framework of customer engagement to brand-hosted social media. Journal of Business Research, 85, 175-184.

So, K. K. F., King, C., Sparks, B. A., \& Wang, Y. (2016). Enhancing customer relationships with retail service brands: The role of customer engagement. Journal of Service Management, 27(2), 170-193.

Stander, F. W., \& De Beer, L. T. (2016). Towards engagement: A comparison of fan groups in the context of a major South African football club. Journal of Industrial Psychology, 42(1), 1-10.

Stander, F. W., Van Zyl, L. E., \& Motaung, K. (2016). Promoting fan engagement: An exploration of the fundamental motives for sport consumption amongst premier league football spectators. Journal of Psychology in Africa, 26(4), 309-315.

Stephens, J. C., Kopin, D. J., Wilson, E. J., \& Peterson, T. R. (2017). Framing of customer engagement opportunities and renewable energy integration by electric utility representatives. Utilities Policy, 47, 69-74.

Storbacka, K., Brodie, R. J., Böhmann, T., Maglio, P. P., \& Nenonen, S. (2016). Actor engagement as a microfoundation for value co-creation. Journal of Business Research, 69(8), 3008-3017.

Syrdal, H. A., \& Briggs, E. (2018). Engagement with social media content: A qualitative exploration. Journal of Marketing Theory and Practice, 26(1-2), 4-22.

Triantafillidou, A., \& Siomkos, G. (2018). The impact of Facebook experience on consumers' behavioral Brand engagement. Journal of Research in Interactive Marketing, 12(2), 164-192.

Tu, Y. J., Neuhofer, B., \& Viglia, G. (2018). When co-creation pays: stimulating engagement to increase revenues. International Journal of Contemporary Hospitality Management, 30(4), 2093-2111.

Van Doorn, J., Lemon, K. N., Mittal, V., Nass, S., Pick, D., Pirner, P., \& Verhoef, P. C. (2010). Customer engagement behavior: Theoretical foundations and research directions. Journal of Service Research, 13(3), 253-266. 
Van Eijk, C. J., \& Steen, T. P. (2014). Why people co-produce: Analysing citizens' perceptions on co-planning engagement in health care services. Public Management Review, 16(3), 358-382.

Vargo, S. L., \& Lusch, R. F. (2016). Institutions and axioms: an extension and update of service-dominant logic. Journal of the Academy of marketing Science, 44(1), 5-23.

Verhagen, T., Swen, E., Feldberg, F., \& Merikivi, J. (2015). Benefitting from virtual customer environments: An empirical study of customer engagement. Computers in Human Behavior, 48, 340-357.

Verhoef, P. C., Reinartz, W. J., \& Krafft, M. (2010). Customer engagement as a new perspective in customer management. Journal of Service Research, 13(3), 247-252.

Viswanathan, V., Malthouse, E. C., Maslowska, E., Hoornaert, S., \& Van den Poel, D. (2018). Dynamics between social media engagement, firm-generated content, and live and time-shifted TV viewing. Journal of Service Management, 29(3), 378-398.

Vivek, S. D., Beatty, S. E., \& Morgan, R. M. (2012). Customer engagement: Exploring customer relationships beyond purchase. Journal of Marketing Theory and Practice, 20(2), 122-146.

Vivek, S. D., Beatty, S. E., Dalela, V., \& Morgan, R. M. (2014). A generalized multidimensional scale for measuring customer engagement. Journal of Marketing Theory and Practice, 22(4), 401-420.

Wei, W., Hua, N., Fu, X., \& Guchait, P. (2017). The impacts of hotels' error management culture on customer engagement behaviors (CEBs). International Journal of Contemporary Hospitality Management, 29(12), 3119-3137.

Wijland, R., Hansen, P., \& Gardezi, F. (2016). Mobile nudging: Youth engagement with banking apps. Journal of Financial Services Marketing, 21(1), 51-63.

Wu, J., Fan, S., \& Zhao, J. L. (2018). Community engagement and online word of mouth: An empirical investigation. Information and Management, 55(2), 258-270.

Yıldırım, A., \& Şimşek, H. (2011). Sosyal bilimlerde nitel araştırma yöntemleri. Ankara: Seçkin Yayınları.

Yoshida, M., Gordon, B., Nakazawa, M., \& Biscaia, R. (2014). Conceptualization and measurement of fan engagement: Empirical evidence from a professional sport context. Journal of Sport Management, 28(4), 399-417.

Youssef, Y. M. A., Johnston, W. J., AbdelHamid, T. A., Dakrory, M. I., \& Seddick, M. G. S. (2018). A customer engagement framework for a B2B context. Journal of Business and Industrial Marketing, 33(1), 145-152.

Zhang, T., Lu, C., \& Kizildag, M. (2017). Engaging generation $Y$ to co-create through mobile technology. International Journal of Electronic Commerce, 21(4), 489-516.

Zhang, T. C., Kandampully, J., \& Bilgihan, A. (2015). Motivations for customer engagement in online co-innovation communities (OCCS). Journal of Hospitality and Tourism Technology, 6(3), 311.

Zheng, X., Cheung, C. M., Lee, M. K., \& Liang, L. (2015). Building brand loyalty through user engagement in online brand communities in social networking sites. Information Technology \& People, 28(1), 90-106. 
This Page Intentionally Left Blank 